WIDER Working Paper 2020/31

\title{
Structural transformation and inclusive growth
}

Kuznets' 'developer's dilemma' in Indonesia

Kyunghoon Kim, ${ }^{1}$ Arriya Mungsunti, ${ }^{2}$ Andy Sumner, ${ }^{1}$ and Arief Yusuf $^{2}$

March 2020 
Abstract: We focus on special characteristics of the manufacturing sector, in terms of employment generation and productivity growth, that enable the rapid, resilient economic catch-up of developing countries. We consider the 'developer's dilemma' and the relationship between manufacturing value added or employment shares and trends in income inequality. In Indonesia, structural transformation was growth-enhancing and economic growth inclusive during the decades before the 1997-98 Asian financial crisis. Since then, structural transformation has become notably less growth-enhancing and inclusive growth outcomes have been mixed. Indonesia's structural transformation pattern has shifted, from 'upgrading industrialization' before the crisis to 'stalled industrialization' afterwards. Both periods saw weak Kuznetsian tension, but patterns of structural transformation and inclusive growth beforehand were more 'benign' than patterns after the crisis. The government has adopted diverse social policy programmes and industrial policies to tackle these twin development challenges. We discuss changes in the political economy of development policy-making since the crisis.

Key words: structural transformation, inclusive growth, Indonesia, industrial policy, social assistance

\section{JEL classification: D63, I32, O14, O25}

Acknowledgements: We thank the participants in the 'WIDER Development ConferenceTransforming Economies' organized by UNU-WIDER in Bangkok in September 2019, for providing valuable comments on an earlier draft. We also appreciate Kunal Sen's detailed suggestions on this paper.

\footnotetext{
${ }^{1}$ Department of International Development, King's College London, London, UK; ${ }^{2}$ Department of Economics, Padjadjaran University, Bandung, Indonesia. Corresponding author: kyunghoon.kim@kcl.ac.uk.

This study has been prepared within the UNU-WIDER project Developer's dilemma - structural transformation, inequality dynamics, and inclusive growth.

Copyright (C) UNU-WIDER 2020

Information and requests: publications@wider.unu.edu

ISSN 1798-7237 ISBN 978-92-9256-788-0

https://doi.org/10.35188/UNU-WIDER/2020/788-0
}

Typescript prepared by Luke Finley.

The United Nations University World Institute for Development Economics Research provides economic analysis and policy advice with the aim of promoting sustainable and equitable development. The Institute began operations in 1985 in Helsinki, Finland, as the first research and training centre of the United Nations University. Today it is a unique blend of think tank, research institute, and UN agency — providing a range of services from policy advice to governments as well as freely available original research.

The Institute is funded through income from an endowment fund with additional contributions to its work programme from Finland, Sweden, and the United Kingdom as well as earmarked contributions for specific projects from a variety of donors.

Katajanokanlaituri 6 B, 00160 Helsinki, Finland

The views expressed in this paper are those of the author(s), and do not necessarily reflect the views of the Institute or the United Nations University, nor the programme/project donors. 
In this paper we focus on the 'developer's dilemma'- the distributional tension between structural transformation and inequality that Kuznets (1955) hypothesized-in Indonesia. We analyse how the quality of structural transformation and inclusive growth has evolved over time. We are particularly interested in how the manufacturing sector's role changed between the 1960s and the 2000 s, and we relate the patterns of structural transformation to trends in poverty and inequality. While Indonesia experienced weak Kuznetsian tension during the periods both before and after the 1997-98 Asian financial crisis, there were notable differences in the economic outcomes in these periods. An important factor that can explain this economic growth differential is the performance of the manufacturing sector. This paper demonstrates that the concurrent expansion of the manufacturing sector's value added and employment shares, or 'upgrading industrialization', stimulated economic growth before the crisis, but that Indonesia experienced 'stalled industrialization' after the crisis.

The paper focuses on the trends of structural transformation and inclusive growth from a historical perspective. A country's overall economic performance depends on the patterns and characteristics of structural transformation, which we define as the changes in an economy's value added, employment, and trade composition (McMillan et al. 2014; Sen 2019). We are particularly interested in the central role that the manufacturing sector plays in structural transformation and inclusive growth. We focus on manufacturing because of the sector's special characteristics in terms of employment generation and productivity growth that enable the rapid and resilient economic catch-up of developing countries. We define inclusive growth as economic growth that benefits a broad section of the population, and particularly the poorer groups (Sen 2014). While these benefits can be identified using diverse measures, this paper uses monetary poverty and inequality data to assess inclusive growth. It also examines changes in formal and informal employment composition as a key link between structural transformation and inclusive growth. It then focuses on the policies that the Indonesian government has implemented to solve the challenges related to structural transformation and inclusive growth over the past decade, when the government began to adopt policies to deal with the effects of the end of the commodity boom, and of slowing economic growth and poverty reduction. We provide a comparative analysis with the period before the Asian financial crisis, with a focus on the changes in the political economy.

Indonesia's economic history in the past half century can be split into the periods before and after the 1997-98 Asian financial crisis. Prior to the crisis, there were some two decades of growth, with impressive performance in terms of structural transformation and inclusive growth. During this period, the modern (non-agricultural) sector expanded rapidly while the agricultural sector's relative position shrank. Indonesia also experienced a notable decline in poverty. Since the crisis, however, manufacturing-led structural transformation has stalled and performance in inclusive growth has been more mixed, even though growth has been reasonable and stable. Between 2000 and 2017, Indonesia's GDP grew by 5.4 per cent per annum and GDP per capita grew by 3.9 per cent per annum. Compared with the oil boom-and-bust of the 1970s and 1980s and the chaotic economic and political events at the end of the 1990s, this recent period was characterized by stability. Compared with other developing countries, the stability in Indonesia's economic growth, measured as standard deviation of the annual economic growth rate in Figure 1, has been outstanding. Moreover, various social indicators, ranging from monetary poverty rates to health and education provision, have improved, although inequality has increased. Despite these achievements, further economic advancement is required in order to raise the living standards of 
those left behind. Yet the Indonesian economy is struggling to accelerate economic growth, as its structural transformation has been less dynamic compared with the period before the crisis.

Figure 1: GDP growth rate and standard deviation of GDP growth rate, major emerging and developing countries Standard deviation of GDP growth rate, 2000-17

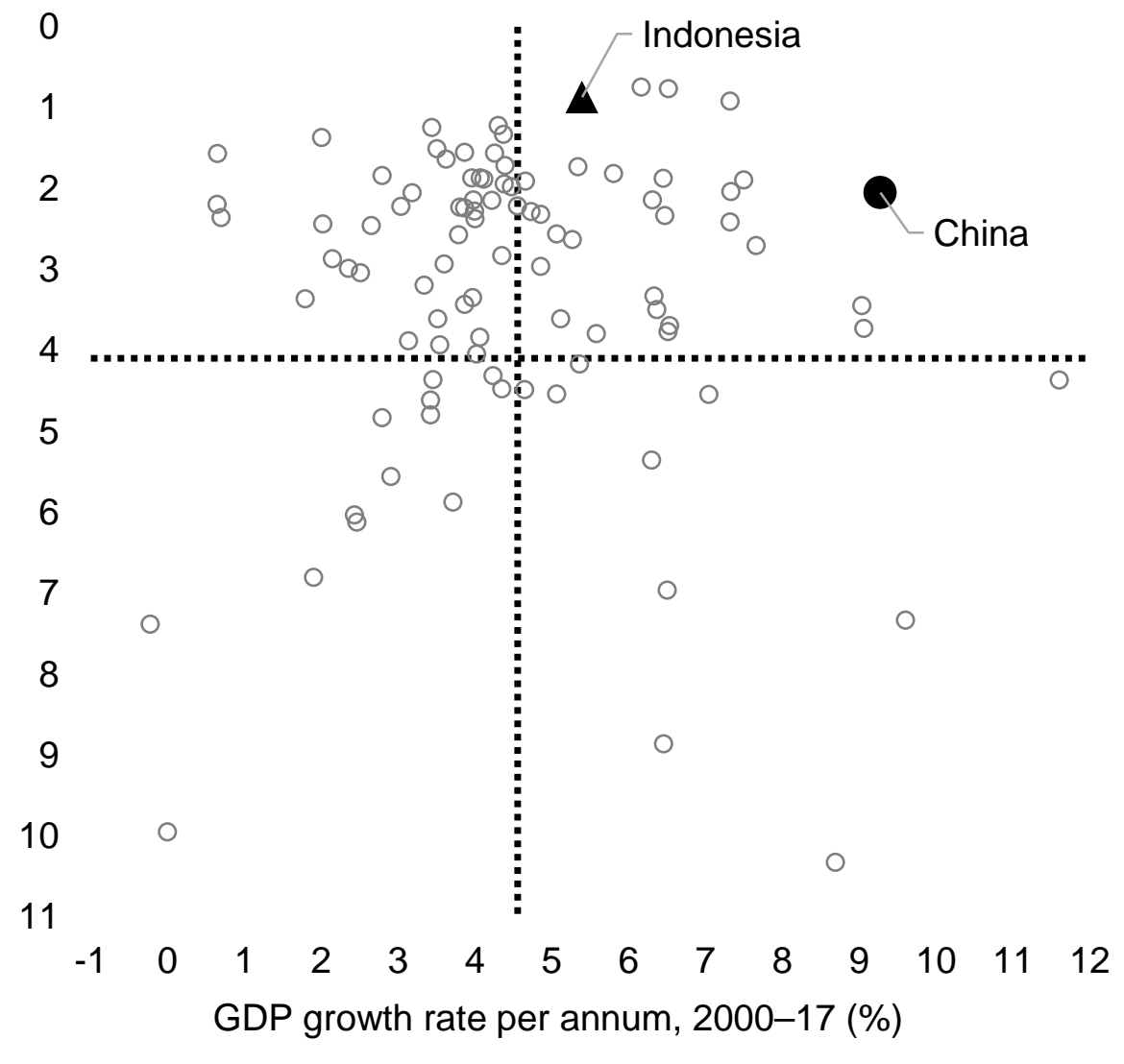

Notes: (i) 100 largest emerging and developing countries in terms of GDP in 2017; no data for Afghanistan or Venezuela; Equatorial Guinea, Iraq, and Libya are not shown in the graph. (ii) Dotted lines show the averages of each variable.

Source: authors' illustration based on IMF (2019).

Indonesia had GDP per capita that was 68 per cent greater than that of China in 1997. However, in 2017, Indonesia's GDP per capita was equivalent to just 45 per cent of China's GDP per capita. The problem is not that structural transformation has not been advancing but that it has become less growth-enhancing. Since the late 1990s, the agricultural shares in both value added and employment have continued to shrink, while the expanding economic sectors have largely been services with relatively low productivity. This pattern contrasts with the structural transformation that Indonesia experienced over the decades before the Asian financial crisis. During this previous period, manufacturing was an important driver of structural transformation, while some services sectors also experienced notable growth in relative productivity. In future, structural transformation that looks different to the recent pattern is required in order to achieve more dynamic economic development.

Although inequality has consistently risen since the end of the 1990s, poverty rates have declined at a reasonable pace using the national poverty line, which is close to the US $\$ 1.90$-per-day global line. In other words, structural transformation has lost dynamism compared with the past, yet it has produced sufficient economic growth to bring down the extreme poverty rate at least. That said, a large proportion of the population is not that far from this line and would potentially be at 
risk if there were an economic shock. Also, if Indonesia continues to depend on lower-productivity sectors to drive structural transformation, and records medium-paced economic growth, then the country is expected to struggle to reduce poverty measured at higher thresholds. Moreover, high levels of inequality will make poverty reduction more difficult at any rate of economic growth.

The government has been expanding social assistance programmes to support the poor and deal with the rising inequality. More recently, it has also started to adopt 'new developmentalist' policies that involve non-tariff barriers and state-owned entities (Kim, 2019a). Yet Indonesia's development spending remains low and fragmented due to strong competition over limited fiscal resources (World Bank 2018). To solve an array of development challenges, the Indonesian government needs much larger government revenues given the institutionalized limits on discretionary spending.

This paper is structured as follows. Section 2 provides an overview of the developer's dilemma in Indonesia by analysing the patterns of structural transformation and inclusive growth. This section describes the key trends of the manufacturing sector and income inequality during the selected periods from the viewpoint of the Kuznetsian tension. Section 3 provides a historical narrative of Indonesia's economic performance before 1960-the period prior to Indonesia's modern structural transformation taking off. On the inclusivity front, the Indonesian economy experienced high levels of inequality along various dimensions during this period. Section 4 shifts the focus to the period between 1960 and 2010. It analyses the changing sectoral drivers of Indonesia's structural transformation and the poverty and inequality trends over time. This section finds that while Indonesia experienced 'upgrading industrialization' for most of the period before the Asian financial crisis, 'stalled industrialization' has been the major trend since the late 1990s, along with rising inequality. Section 5 finds that the combination of 'stalled industrialization' and rising inequality continued during the 2010s. It also analyses the policies adopted to fix the recent patterns of structural transformation and inclusive growth, and provides a comparison between the political economic environments in which the government pursued activist policies before and after the Asian financial crisis. Furthermore, this section highlights some of the key issues that could shape the future patterns of structural transformation and inclusive growth. The last section concludes.

\section{The developer's dilemma in Indonesia: an overview}

Before a detailed historical narrative is discussed in the later sections of this paper, this section provides key evidence which shows Indonesia's twin development challenges of weakening structural transformation and inclusive growth. When we talk of the developer's dilemma, we can think about the changes in manufacturing value added or employment shares and trends in income inequality, and their relationship. Figure 2 plots gross income Gini coefficients against the manufacturing value added share in constant prices (Figure 2a) and the manufacturing employment share (Figure 2b). Figures $2 \mathrm{a}$ and $2 \mathrm{~b}$ suggest that we can divide the period between the 1960s and the 2010s into three subperiods with distinctive patterns of manufacturing shares and inequality. The first period ('cliff 1') is between the mid-1960s and the mid-1970s, when Indonesia's manufacturing sector was at an infant stage and recorded limited expansion, with the manufacturing value added share hovering around 10 per cent. During this period, Indonesia's inequality rose rapidly. The second period ('downhill') is between the mid-1970s and the mid1990s. The manufacturing sector's value added and employment shares expanded rapidly during these two decades. At the same time, Indonesia experienced a notable decline in inequality, with the Gini coefficient returning to a level similar to that of the mid-1960s. The last period ('cliff 2') includes the 2000s and the early 2010s. The trend in this third period is somewhat similar to that in the first period ('cliff 1'). The manufacturing value added and employment shares stagnated 
during the first half of the 2000s and then declined slightly. During this period, inequality increased notably.

Figure 2: Manufacturing development and inequality trends, Indonesia

2a: Value added share

(Gross income Gini)

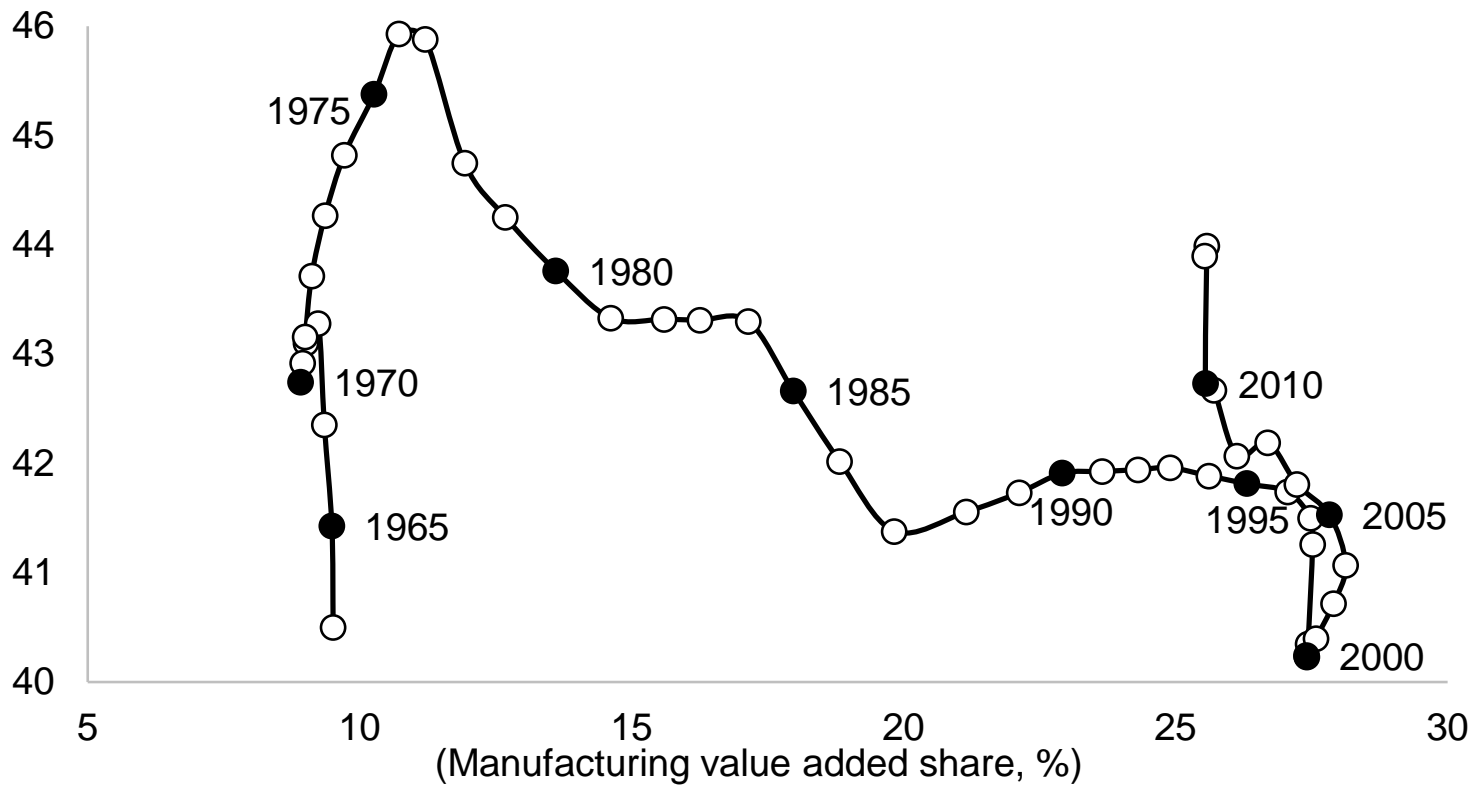

2b: Employment share

(Gross income Gini)

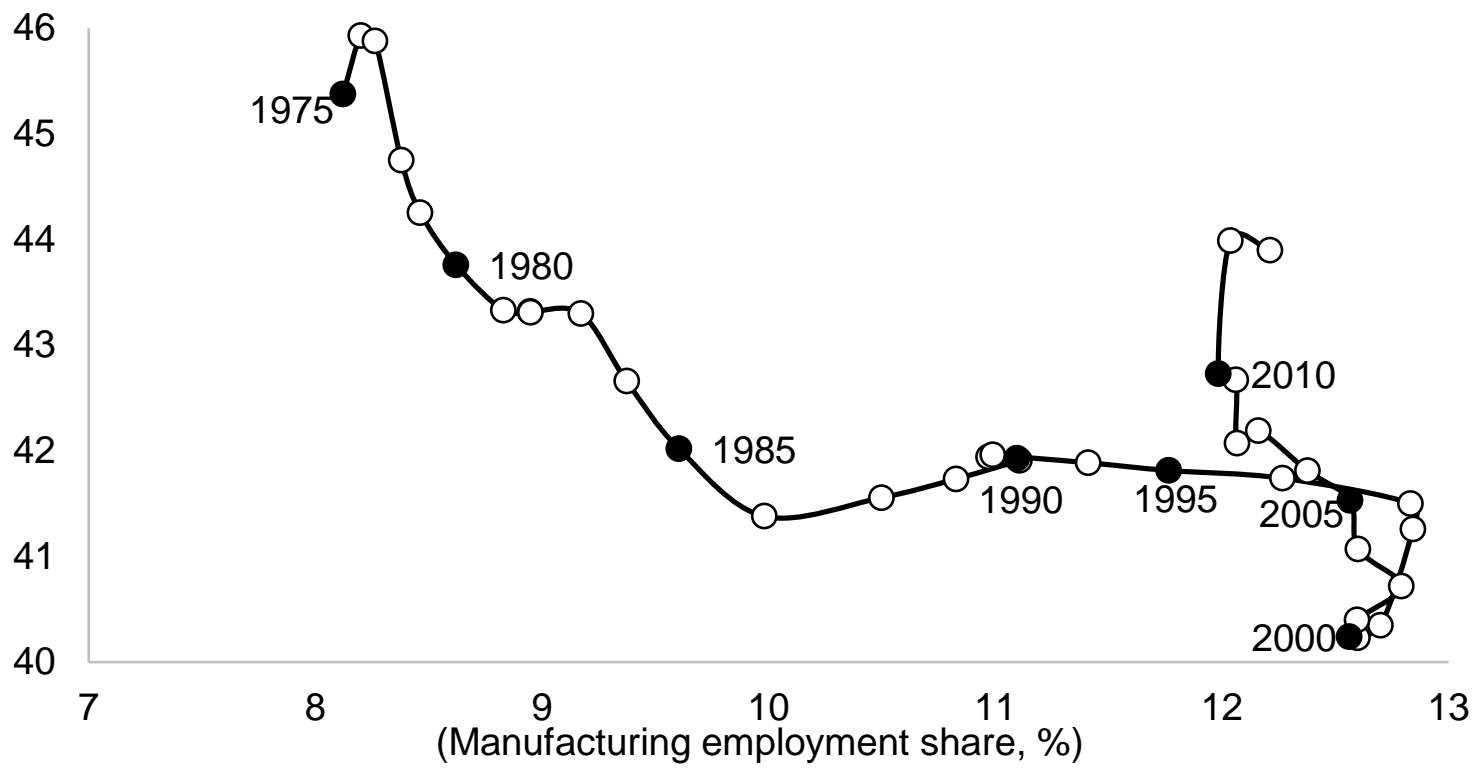

Notes: (i) The missing Gini coefficients were calculated using linear interpolation; see Figure 9 for the original data. (ii) Manufacturing value added and employment shares are five-year moving averages-for example, the figure for 1975 is an average of data for 1971-75; see Figures 4 and 5 for the original data.

Source: authors' calculations based on GGDC (Groningen Growth and Development Centre) 10-Sector Database Version 2015 (Timmer et al. 2015) and UNU-WIDER's World Income Inequality Database (WIID).

Analysing Indonesia's economic composition and inclusive growth, we do not find a period during which Indonesia experienced strong Kuznetsian tension, or a simultaneous increase in inequality 
and rapid growth-enhancing structural transformation (Figure 3). While Indonesia experienced weak Kuznetsian tension during the three periods, the outcomes were markedly different. During the second period ('downhill'), Indonesia went through strong growth-enhancing structural transformation with notable growth of the manufacturing value added and employment shares, or 'upgrading industrialization' (Kim and Sumner 2019). The economic situation was benign during this period, as the country experienced rapid GDP growth and improvement in living standards as well as a decline in income inequality. In comparison, Indonesia experienced weak growthenhancing structural transformation and a rise in inequality in the first and third periods ('cliff 1' and 'cliff 2') and therefore the situation was more adverse. During these two periods, Indonesia went through 'stalled industrialization' with limited change in the manufacturing value added and employment shares.

Figure 3: Kuznetsian tension by period, Indonesia

\begin{tabular}{|c|c|c|}
\hline Increasing & $\begin{array}{l}\text { Kuznetsian tension: } \\
\text { Weak ('adverse') } \\
\text { Period I } \\
\text { (1960s-mid-1970s) } \\
\text { Period III } \\
(2000 \text { s-) }\end{array}$ & $\begin{array}{l}\text { Kuznetsian tension: } \\
\text { Strong }\end{array}$ \\
\hline $\begin{array}{l}\text { Stable or } \\
\text { declining }\end{array}$ & $\begin{array}{l}\text { Kuznetsian tension: } \\
\text { Ambiguous }\end{array}$ & $\begin{array}{l}\text { Kuznetsian tension: } \\
\text { Weak ('benign') } \\
\text { Period II } \\
\text { (mid-1970s-mid-1990s) }\end{array}$ \\
\hline $\begin{array}{l}\text { Stable or } \\
\text { declining }\end{array}$ & $\begin{array}{c}\text { Weak } \\
\text { Growth-enhancing s }\end{array}$ & $\begin{array}{c}\text { Strong } \\
\text { uctural transformation }\end{array}$ \\
\hline
\end{tabular}

Source: authors' illustration.

As in the third period, the combination of stagnating manufacturing shares and rising inequality is the twin challenge that Indonesia is currently facing. In light of these two grand development challenges, governments face a dilemma in setting priorities and allocating valuable public resources accordingly. The rest of this paper discusses the structural transformation and inclusive growth trends, the potential drivers, and the government's policies to solve development challenges. 


\subsection{Structural transformation: remaining static}

Between 1900 and 1960, Indonesia's structural transformation was driven by the oil and gas sector. Based on the estimated value added data in constant 2000 prices (Van der Eng 2010), the agricultural share declined gradually from 41.4 per cent in 1990 to 31.0 per cent in 1960, which translates into a decline of just 1.7 percentage points per decade. The industrial value added share expanded from 17.1 per cent to 30.3 per cent. This expansion was driven by the oil and gas sector, with its share increasing by more than 22 times from 0.8 per cent in 1900 to 17.6 per cent in 1960 . The services value added share increased from 41.5 per cent in 1900 to 46.6 per cent in 1921. Then the share began to decline; it was recorded as 38.7 per cent in 1960. Overall, comparing the figures shows that there was not a significant change in the services share between 1900 and 1960 .

During this period, Indonesia failed to achieve sustained industrialization or manufacturing-led structural transformation. Compared with the oil and gas sector, the change in manufacturing value added share was less unidirectional. It declined in the first quarter of the century from 9.0 per cent in 1900 to 6.2 per cent in 1928. Then, during the 1930s, the Dutch authorities encouraged largescale manufacturing development by imposing quotas on Japanese imports and devaluing the currency (Booth 2016: 23-24). Sizeable foreign investment entered Indonesia and supported the setting up of industrial plants in this period (Soehoed 1967: 67). Along with these measures, the manufacturing value added share expanded, reaching 9.1 per cent in 1941. After a sudden decline during the 1940s, the manufacturing value added share recovered from 7.8 per cent in 1950 to 9.4 per cent in 1957, and then fell back to 7.9 per cent in 1960. Soehoed (1967: 69-71) notes that the number of manufacturing firms increased notably in the second half of the 1950s with the state banks' provision of easy credit, but the actual production levels in most manufacturing subsectors did not match this rise, mainly because of scarce exchange allocation for importing raw materials and the government's deflationary measures. Overall, despite some spurts of industrialization, manufacturing remained small, with the share struggling to rise above 10 per cent between 1900 and 1960.

Comparing the 1930 and 1961 censuses, Jones (1966: 51-55) finds that there was limited labour shift from agricultural to non-agricultural sectors. The agriculture, forestry, and fishing sector's employment share did not change much, recorded at 73.9 per cent in 1930 and 73.3 per cent in 1961. The research suggests that the decline in the agricultural share may have been larger if one takes the methodological differences into account but, in any case, the decline would still be much smaller than that in other developing countries such as Malaya and Brazil. During this period, there were some notable changes within the non-agricultural sector. The industrial labour share declined significantly, with the manufacturing share declining from 11.5 per cent to 5.8 per cent and the mining share from 0.9 per cent to 0.3 per cent. More strikingly, the absolute number of workers in these two sectors also declined. The research suggests that the large decline in the manufacturing share may be due to a relative decline of labour-intensive manufacturing, capacity under-utilization, and inconsistency in data collection. During this period, the labour share of services (including utilities) expanded from 13.7 per cent to 18.8 per cent. The research suggests that this expansion is likely to have occurred among those employed in less-productive services, such as rickshaw drivers and petty clerks.

Because of the limited manufacturing development, Indonesia's exports consisted mainly of natural resources and were concentrated in a few commodities during the first half of the twentieth century (Thomas and Panglaykim 1966). Nine commodities accounted for 78.2 per cent of total exports in 1928 and 80.8 per cent in 1938. In 1928, the major export products were sugar (23.6 
per cent), rubber (17.6 per cent), and petroleum and petroleum products (7.2 per cent). Over the following decade, the importance of sugar exports weakened while that of oil exports strengthened. The major export products in 1938 were petroleum and petroleum products (24.9 per cent), rubber (19.9 per cent), and tea (8.6 per cent). Between 1950 and 1960, eight commodities continuously accounted for more than four-fifths of total exports, with their export share averaging 90 per cent. In 1950, rubber (42.8 per cent), petroleum and petroleum products (18.4 per cent), and copra (7.2 per cent) were the largest export products. The importance of oil exports increased rapidly in the mid-1950s, with the share of petroleum and petroleum products increasing to as high as 39.9 per cent in 1958. In 1960, rubber (44.8 per cent), petroleum and petroleum products ( 26.3 per cent), and tin ( 6.0 per cent) were the largest export products.

Soekarno, the war leader during the struggle for independence and Indonesia's first president, struggled to stimulate structural transformation during his two decades in power between the mid1940s and mid-1960s. The president was preoccupied with dealing with internal political issues, namely the conflict between the communists and other political factions, even after he established an autocratic system in the late 1950s. The government pursued state-led development from the late 1950s onwards, after mass nationalization of Dutch companies, but the state enterprises were heavily used to serve the vested interests of the military and politico-bureaucrats. The government also lacked the additional capital necessary to spearhead structural transformation. During this period, private firms did not have the capacity to mobilize the resources needed to make meaningful investment in modern economic sectors and many struggled to survive as infrastructure remained weak and the government mismanaged the economy (Lindblad 2008: 177208; Robison 1986: 69-97). The inflation rate was recorded at 109 per cent in 1963 and 307 per cent in 1964, and reached 1,136 per cent in 1965.

Overall, structural transformation played a limited role in Indonesia's economic growth in the first 60 years of the twentieth century. The country continued to depend heavily on the natural commodity sector, and oil and gas in particular. Given the political and economic instability around 1960, it would have been difficult to imagine Indonesia joining the rank of Asia's rapidly growing economies in the near future.

\subsection{Inclusive growth: slow progress}

Numerous indicators show that there was slow progress in raising living standards during the first half of the twentieth century. Comparing socioeconomic indicators for the 1930s and 1950s, Booth (2016: 52-55) demonstrates that life expectancy increased only slightly, from 35 years to 37.5 years, and suggests that living standards may have deteriorated by highlighting a decline in Indonesia's real GDP per capita, Java's basic foods consumption per capita, and Jakarta's real monthly food expenditure per capita.

During this period, the level of inequality was high in Indonesia. Using income taxation data, Leigh and Van der Eng (2009) offer an estimation of the top income shares between 1920 and 1939. They find that the income share of the richest 1 per cent increased from 11.8 per cent in 1921 to 16.6 per cent in 1930 and 21.5 per cent in 1934. This research suggests that the sudden jumps in inequality in the early 1920 s and the early 1930s were partly due to the large falls in the price of agricultural export products, which caused a significant decline in the relative incomes of farm households. While the price movements of agricultural products hit many rural households, they had limited impact on non-farm salary earners. Towards the end of the 1930s, the income share of the richest 1 per cent fell slightly, to 19.9 per cent in 1939 .

Van Leeuwen and Földvári (2016) confirm the high levels of inequality during the first half of the twentieth century. By estimating the expenditure Gini coefficients, this study finds that overall 
inequality and rural-urban inequality rose rapidly between 1925 and 1932. It suggests that the rise in overall inequality is consistent with the hypothesis of Lindert and Williamson (2003). This hypothesis argues that the rise in inequality prior to the 1930s was due to changing characteristics within the agricultural sector, such as a shift in the sector's focus from the domestic market to exports, which led to a greater use of abundant land and therefore a rise in land rents relative to wages. After the fall in the price of commodity exports during the 1930s, Indonesia's expenditure Gini continued to rise, but this time the rise was caused by a decline in the income share of richer agricultural households relative to the urban sector. Indonesia's overall inequality then declined between 1942 and 1959, with the effects of the war and the withdrawal of the Netherlands being the potential drivers of this change. Despite a decline in expenditure Gini during this period, it continued to be high, recorded at 51 in 1959.

High levels of inequality were also apparent between businesses, and this type of inequality had ethnic dimensions. During the first decade after independence in 1945, the private indigenous capitalists struggled to compete against larger foreign firms and Chinese Indonesians. The government made efforts to foster the growth of indigenous firms, yet its preferential support measures were often insufficient and inconsistent. While siding with indigenous capitalists was important for maintaining political stability, the government continued to rely on foreign companies and Chinese Indonesians with capital and technology to sustain economic growth. This trend continued even during the period of strong economic nationalism and state-centred development between the late 1950s and the mid-1960s. While on the surface it was the conflict between the military and the communist party that was a primary cause in ending the Soekarno regime in 1967, the continuation of high levels of inequality and slow economic growth had gradually been weakening the regime's legitimacy over the two decades (Robison 1986: 36-98).

\section{Economic development during circa 1960 to circa 2010}

\subsection{Structural transformation: from industrialization to tertiarization}

The role of the manufacturing sector has transformed in Indonesia over the past five decades. This subsection first discusses Indonesia's industrialization before the Asian financial crisis. During this period of 'upgrading industrialization', the government policy focus shifted from import substitution during the 1970s and the early 1980s to export orientation during the late 1980s and the 1990s. The latter half of this subsection discusses how structural transformation became less growth-enhancing while Indonesia went through 'stalled industrialization' after the crisis. ${ }^{1}$

The previous section demonstrated that Indonesia had not begun modern structural transformation during the first six decades of the twentieth century. During the following decade or so, the Indonesian economy continued to depend heavily on natural resources. When Soeharto took over the control of the country in the mid-1960s, Indonesia's economy was in a dire situation. Therefore, rather than searching for direct methods of stimulating structural transformation, the immediate goal of the new regime under Soeharto was to stabilize the macroeconomic conditions. The government succeeded in calming the economic situation in the second half of the 1960s after adopting liberalization measures and opening doors to foreign investors. Using the 10-Sector Database of the Groningen Growth and Development Centre (GGDC), Figure 4 shows that agriculture dominated the economy and occupied approximately 35 per cent of value added at constant 2005 prices during the 1960s (Timmer et al. 2015). Figure 4 shows that the mining sector

\footnotetext{
${ }^{1}$ This subsection builds on Section 3 of Kim et al. (2018).
} 
accounted for approximately 20 per cent of value added during the 1960s and was boosted during the oil boom of the 1970s. The mining sector's share reached a peak of 34.0 per cent in 1973 and stayed above 30 per cent for most years during the 1970s. The merchandise exports-GDP ratio expanded rapidly from the early 1970s, and the share of fuel in total exports stayed above twothirds for most years during the 1970s. The manufacturing sector was still in its infancy, with a value added share in the range of 8.6-9.8 per cent in the 1960s. The World Bank (1981: 1) notes that 'in the late 1960s, the Indonesian manufacturing sector looked much the same as it had 30 years earlier, producing much the same goods, using much the same technology, and in some important cases, in exactly the same factories'. At this time, the future trajectory of structural transformation continued to remain uncertain.

Figure 4: Composition of value added (constant 2005 national prices), Indonesia

(\% of value added)

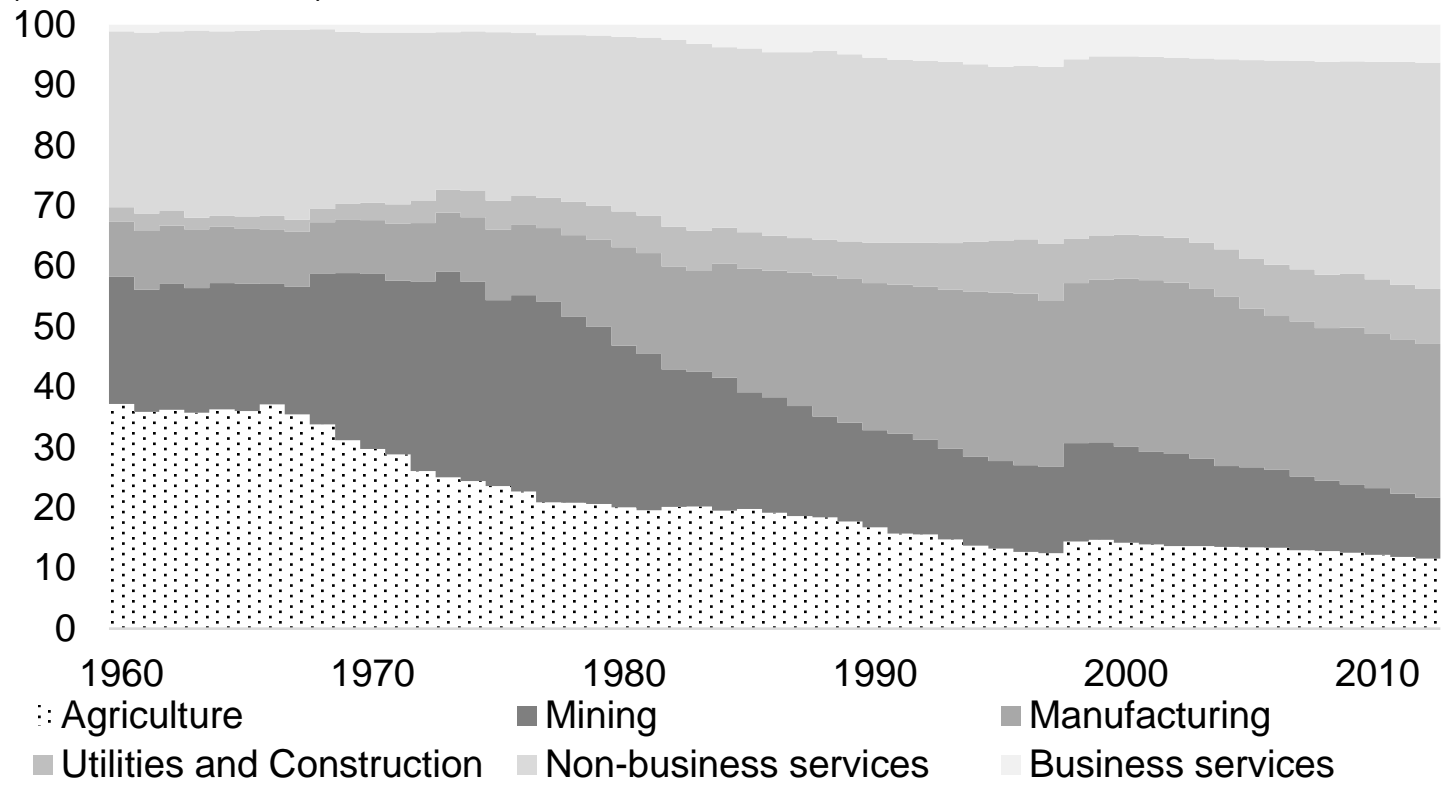

Notes: business services are financial intermediation, renting, business activities. Non-business services are (i) wholesale and retail trade, repair of motor vehicles, motorcycles, and personal and household goods, and hotels and restaurants; (b) transport storage, and communications; (c) public administration, defence, education, health, and social work; and (d) other community, social, and personal services activities and activities of private households.

Source: authors' illustration based on GGDC 10-Sector Database Version 2015 (Timmer et al. 2015).

Then, the value added shares of the agricultural sector and the mining sector began to decline from the late 1960s and the late 1970s respectively, and Indonesia's modern structural transformation began. Figure 4 shows that the growth of the manufacturing sector accelerated in the mid-1970s and contributed to the rapid economic development of the following two decades. The value added share of the manufacturing sector increased from 11.6 per cent in 1975 to 20.5 per cent in 1985 and 27.9 per cent in 1995. The rise in the manufacturing sector's employment share was also notable-from 7.9 per cent in 1971 to 9.2 per cent in 1980 and 13.4 per cent in 1995 (Figure 5). Fujita and James (1997) show that a large increase in employment in the manufacturing sector from the 1980s onwards was due to the rapid growth of export-orientated industries. In particular, labour-intensive light manufacturing segments recorded impressive growth in output and created a large number of jobs. With the rise in the manufacturing value added and employment shares, Indonesia experienced a period of 'upgrading industrialization'. As will be discussed further in the next section, this period coincided with a rapid decline in inequality, represented as 'downhill' in Figure 2. 
Figure 5: Employment composition, Indonesia

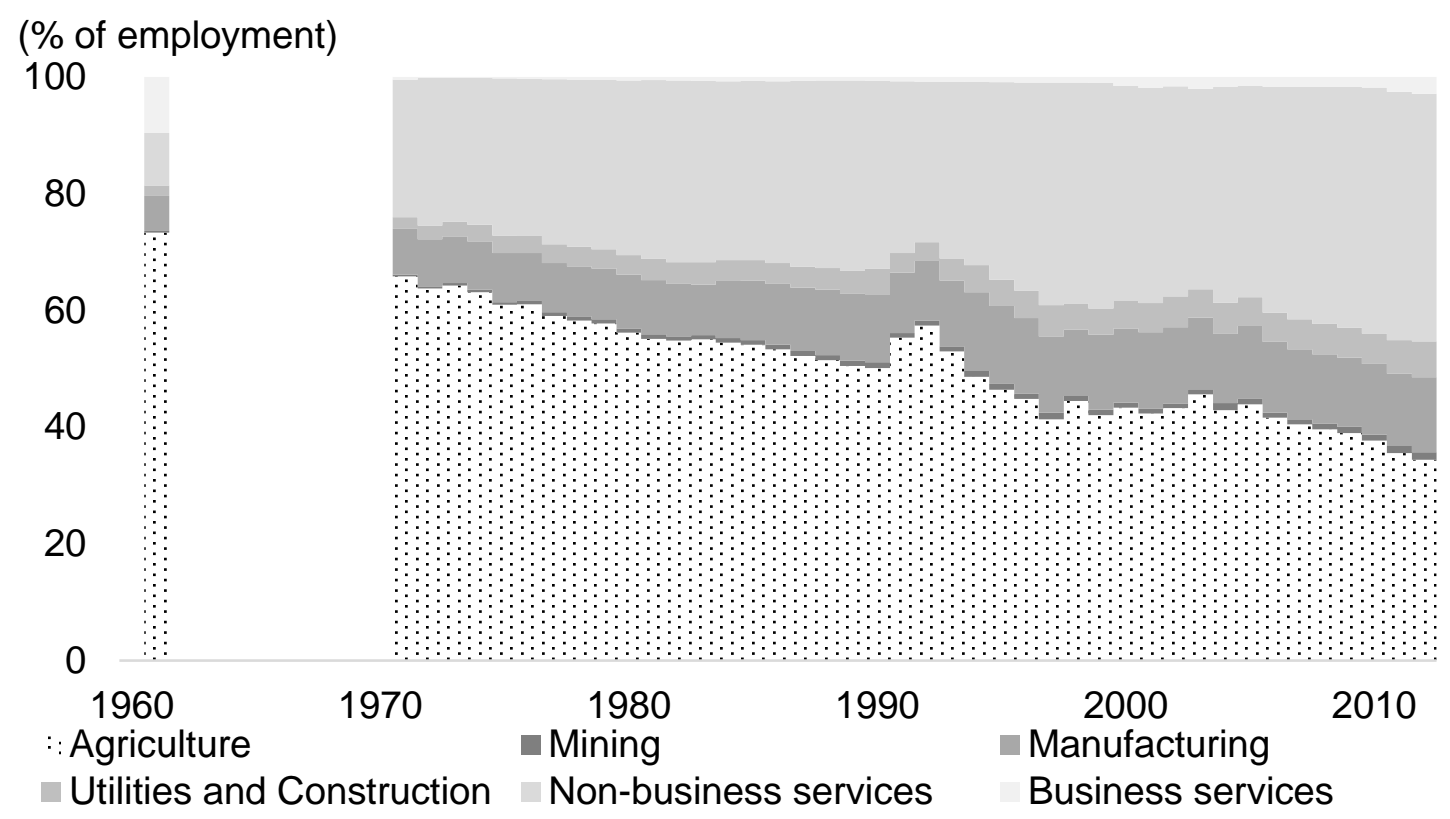

Notes: see notes to Figure 4.

Source: authors' illustration based on GGDC 10-Sector Database Version 2015 (Timmer et al. 2015).

The manufacturing sector grew between the mid-1970s and the mid-1980s, along with the government's protectionist measures, import substitution policies, and significant state investments in manufacturing and infrastructure using revenues from oil exports. The government was a central investor in resource processing and capital-intensive industries. One notable feature in Indonesia's economic development during the oil boom is that the country did not suffer much from the Dutch disease. Comparing the development trajectories of Nigeria and Indonesia, Lewis (2005: 106-12) argues that Indonesia could largely avoid the Dutch disease, unlike Nigeria, because its policy makers seriously considered the importance of macroeconomic stability, structural transformation, and balanced growth. The government's concerns on these issues led to their devaluing the currency in 1978 and making massive and sustained capital investment in infrastructure and the agricultural and manufacturing sectors during the oil boom. Usui (1997) also finds that these policies explain the superior performance of Indonesia over Mexico during the oil boom. Additionally, Usui demonstrates that Indonesia's fiscal budget policies and foreign borrowing policies were managed more appropriately.

However, the development strategy centred on active government intervention became unsustainable with the decline in international oil prices from the mid-1980s. Other international factors, such as the increase in the relative value of Indonesia's debt after the appreciation of the yen and a rise in global real interest rates, also put pressure on Indonesia's current account and fiscal position. In these circumstances, the Indonesian government took a decisive step to liberalize the economy. The rapid expansion of the manufacturing sector from the mid-1980s onwards was therefore related to a series of economic reform policies adopted by the government, including the restructuring of customs services and the lifting of foreign investment restrictions (Aswicahyono et al. 1996; Fane 1999; Feridhanusetyawan and Pangestu 2003). Figure 6 shows that the manufacturing sector's share in merchandise exports expanded rapidly from the early 1980s to the mid-1990s. Jacob (2005) shows that the surge in manufacturing exports was driven by resourceintensive manufacturing, including food and wood products, and labour-intensive manufacturing, such as garments and textiles. 
During this period, there was a rise in export-orientated investment from higher-income Asian economies, whose companies sought potential industrial bases with low-cost labour as wages in their home countries increased. These companies were attracted to the economic liberalization policies adopted by the Indonesian government in the mid-1980s (Thee 1991). Further, the importance of exchange rate values vis-à-vis North-East Asia cannot be underplayed. The G5 agreement in September 1985 (known as the Plaza Accord) had an important impact in making Indonesia more competitive in terms of labour costs. The yen and the German Deutschemark increased in value relative to the US dollar, and Indonesia had major devaluations in 1983 and 1986. During this period, the rupiah depreciated against the dollar and the yen in particular. Devaluations also affected Indonesia's exchange rates against the Korean, Taiwanese, and Singaporean currencies. As a result, Indonesia, having already built significant physical infrastructure in the 1970s, became an attractive place for foreign direct investment (FDI). Furthermore, the withdrawal of privileges from the North-East Asian economies in 1988 under the US General System of Preferences induced with even greater force the relocation of capital from North-East to South-East Asia.

Figure 6: Export composition, Indonesia

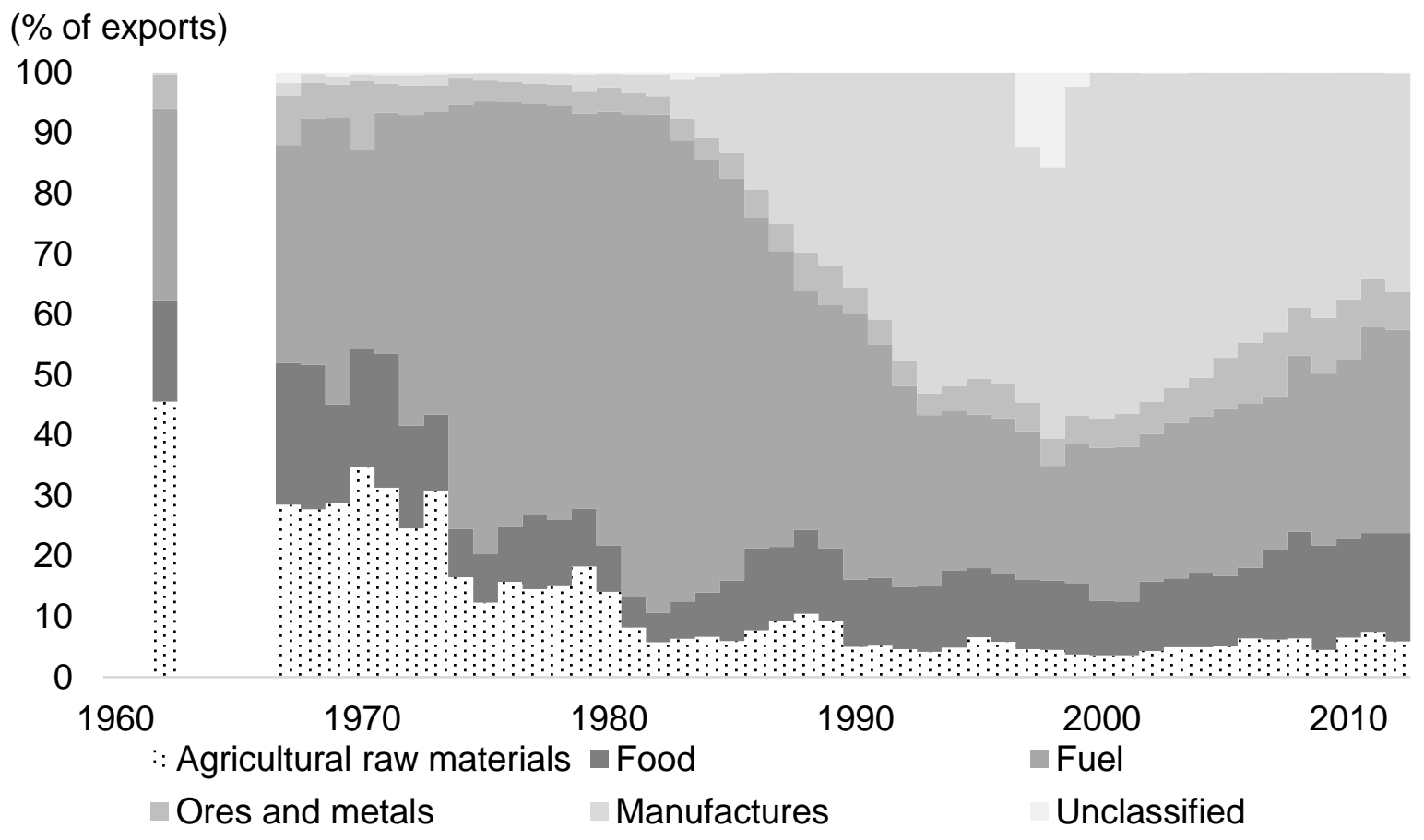

Source: authors' illustration based on World Development Indicators, June 2019 version (World Bank 2019b).

However, the economic liberalization measures failed to put Indonesia on a sustainable path. At the end of the 1990s, it faced one of the most severe crises in its modern economic history, with a massive capital withdrawal from the country. The GDP growth rate plummeted from 7.8 per cent in 1996 to 4.7 per cent in 1997 and -13.1 per cent in 1998. The investment rate declined from 32.2 per cent of GDP in 1997 to 19.2 per cent of GDP in 1998. The economic recovery was slow, with GDP in constant prices reaching the pre-crisis peak only in 2003.

During and after the Asian financial crisis, the president's family businesses and private oligarchs were identified as the central culprits. Indonesia's oligarchs, many of whom were Chinese Indonesians with massive wealth and links with the dictator, had seen their businesses grow rapidly over the previous three decades. The Soeharto regime relied on the oligarchs to drive economic growth and provide political funding, especially during periods of fiscal difficulty. In return, the 
government offered them lucrative deals and subsidized credit and inputs. At the same time, Chinese Indonesian businesses depended heavily on the Soeharto regime, as they continued to be socially and politically vulnerable. When anti-Chinese sentiment heightened during the mid-1970s, the government adopted various measures aimed at supporting indigenous companies. However, the effects of these measures often fell short of expectations, as the indigenous firms lacked the necessary financial capacity and business competitiveness to take advantage of the government policies. Chinese Indonesian businesses often found methods of circumventing these regulations, and the government loosened or did not adhere to these measures when faced with practical difficulties. By the late 1970s, it was estimated that Chinese Indonesians owned at least 70-75 per cent of private domestic capital (Robison 1986: 271-77).

Economic liberalization from the mid-1980s provided Chinese Indonesian businesses with an environment for rapid growth. By this time, they had built a strong corporate and financial foundation that enabled them to compete against foreign firms. With the weakening fiscal position after the oil boom, the Soeharto regime's economic reliance on Chinese Indonesian businesses strengthened. As a result, Soeharto's crony relationship with Chinese Indonesians deepened further. Strong financial power and political connections made Chinese Indonesian businesses an attractive partner for foreign investors during the liberalization period (Chua 2008; Robison and Hadiz 2004). Furthermore, Soeharto's children started to enter the business scene, while indigenous capitalists became increasingly marginalized (Fukuoka 2015: 425-26). During liberalization, the oligarchies expanded investment, often in rent-heavy industries, by sourcing external finance. As many conglomerates owned their own banks after the banking sector deregulation of the 1980s, channelling finance for their business expansion was not difficult. Also, the oligarchs' political connections meant that they could bypass financial sector rules, which were insufficient in any case, to allow their businesses and banks to take excessive risks. Figure 4 shows a rapid expansion of the financial sector during the 1980s and the first half of the 1990s. From the early 1990s, the foreign borrowing of Indonesian banks and private companies increased rapidly (Suhaedi and Wibowo 2011:111-18). A large proportion of the increase in foreign debts was shortterm loans. Radelet et al. (1998: 25-26) show that the ratio of short-term debts borrowed from foreign banks to foreign exchange reserves was 1.9 in Indonesia at the end of 1995-the highest among Asia's major developing countries. Large foreign short-term debts made the Indonesian economy particularly vulnerable to financial panic. Financial liberalization also meant that moving capital out of the country had become easier for both domestic and foreign investors. The financial bubble and investment frenzy came to an end with the 1997 financial crisis, which involved rapid capital withdrawals and a substantial depreciation of the rupiah.

The economic turmoil, combined with political uncertainty after the end of Soeharto's 32-yearlong rule, destabilized Indonesia's business environment. The country's net FDI inflow was negative for four consecutive years, while Korea, Malaysia, and Thailand, which were also severely affected by the crisis, did not record even a year of negative net FDI inflow. A lack of international capital had a significant impact on Indonesia's manufacturing sector, in which foreign companies had played an important role. The dramatic depreciation of the rupiah during the crisis was not sufficient to lead to an immediate recovery of export-orientated domestic companies because many of them also suffered from an increase in foreign debt. After the crisis, the government embarked upon another wave of economic liberalization under the auspices of the IMF.

During the 2000s, the manufacturing sector failed to return to the long-term growth experienced between the 1970s and the mid-1990s. After reaching a peak of 28.4 per cent in 2001, the value added share of the manufacturing sector declined to 25.4 per cent in 2006 and flattened out. The manufacturing employment share declined from 13.1 per cent in 1997 to 11.3 per cent in 1998 and averaged 12.4 per cent up to 2012, with small annual fluctuations. In other words, Indonesia went 
through 'stalled industrialization'. During this period, Indonesia experienced a notable increase in inequality, represented as 'cliff 2' in Figure 3. Further, Figure 6 shows that the share of manufacturing goods in merchandise exports declined rapidly following the Asian financial crisis. ${ }^{2}$ Due to weak manufacturing exports, combined with a rapid expansion of fuel imports, Indonesia's trade balance deteriorated during the 2000 s. $^{3}$

However, the downturn of the manufacturing sector's value added share cannot be solely attributed to the Asian financial crisis. There were already signs of slowdown in the manufacturing sector prior to the crisis. Szirmai (1994) and Timmer (1999) show that the productivity growth of Indonesia's manufacturing sector accelerated from the mid-1980s, but the pace did not match that of other industrializing economies in Asia. Thee (2006) notes that a number of studies recommended that the government deepen and broaden Indonesia's manufacturing base in the mid-1990s to make manufacturing-led structural transformation sustainable. However, Indonesia's manufacturing sector continued to be concentrated in few labour-intensive and resource-based segments, in which global competition intensified with the entry of new contestants such as China during the 2000s. The growth of certain more capital-intensive manufacturing segments accelerated during the 1990 s, but their sustainability was questionable. For example, Aswicahyono et al. (2000) show that the automobile industry continued to be heavily protected even during the country's liberalization. They argue that the government's strong regulation and protective measures allowed automotive firms to benefit from technological learning to a certain extent, though these measures also made the sector highly fragmented. Moreover, Jacob and Meister (2005) argue that knowledge spillovers from FDI had an insignificant effect on productivity in Indonesia's manufacturing sector due to limited domestic absorptive capacity.

Since the Asian financial crisis, the shares of two other industrial sectors-namely the electricity, gas, and water supply sector (henceforth, utilities) and the construction sector-expanded although their initial sizes were relatively small. Between 1998 and 2012, these two sectors' aggregate value added share increased from 7.3 per cent to 9.1 per cent and their aggregate employment share increased from 4.5 per cent to 6.1 per cent. The value added share of the mining sector continued to decline, from 16.3 per cent in 1998 to 10.1 per cent in 2012, while the employment share averaged 1.0 per cent without much change during this period.

Next, we take a look at the growth pattern of the services sector since the 1960s. The value added share of the services sector remained at approximately 30 per cent in the 1960s and 1970s. The services sector's value added share only began to expand substantially during the 1980s after two decades of limited change (see Figure 4): it increased from 30.9 per cent in 1980 to 36.1 per cent in 1990 and remained at approximately this level until the Asian financial crisis. The growth of services was led by the finance, insurance, real estate, and business services (henceforth, business services) sector in this period, whose share more than tripled from 2.0 per cent in 1980 to 7.0 per cent in 1997. The Indonesian government carried out major reforms in the banking industry in 1983 and 1988, and deregulation invigorated investments in finance-related sectors. The wholesale and retail trade, hotels, and restaurants (henceforth, trade services, included in 'non-business

\footnotetext{
${ }^{2}$ It is worth highlighting that the export share of fuel, ores, and metals expanded during the 2000s with the global commodities boom. This trend is reflected in the rising value added share of the mining sector at current prices, though the value added share at constant prices shows a sustained decline during this period.

${ }^{3}$ An increase in fuel imports was a result of rising domestic demand, declining domestic oil production, and limited progress in the expansion of the country's refinery capacity.
} 
services' in Figure 4) sector also showed significant growth, with its share rising from 12.3 per cent in 1980 to 15.4 per cent in 1997.

Following the Asian financial crisis, Indonesia's services value added share increased rapidly from 34.8 per cent in 2000 to 43.8 per cent in 2012. The transport, storage, and communication (henceforth, transport services, included in 'non-business services' in Figure 4) sector grew particularly rapidly, with its share more than doubling from 4.6 per cent in 2000 to 10.1 per cent in 2012. This sector's explosive growth can partly be attributed to regulatory reform in the telecommunications sector, which attracted large investments, and rising mobile phone and internet penetration in Indonesia. Trade services also recorded resilient growth, with their share reaching 17.1 per cent in 2012. The community, social, and personal services (henceforth, personal services, included in 'non-business services' in Figure 4) sector showed impressive growth during the 2000s after three decades of steady decline. Business services' share shrank by nearly a quarter after the Asian financial crisis but began to recover in the early 2000s. The services-led structural transformation coincided with consumption-driven economic growth in Indonesia. During this period, the economically secure population and the middle class residing in urban areas expanded, and their ability to increase discretionary spending led to a rapid growth in demand for consumer services (Oberman et al.2012).

The services sector's central role in the recent structural transformation is also evident in terms of employment (Figure 5). The long-term shift in the composition of sectoral employment was disrupted during the Asian financial crisis and its aftermath. The long-term trend of the declining employment share of the agricultural sector was halted between 1997 and 2005 as the crisis forced a considerable number of workers back into agriculture. During the crisis, a large number of workers in the industrial sector lost jobs. The industrial sector's employment share declined by 2.8 percentage points - nearly nine times larger than the change in the services share. The lay-offs were particularly severe in manufacturing. In 1998, the number of workers in the manufacturing sector shrank by almost 1.5 million compared with the previous year. When structural transformation began again in the mid-2000s, the services sector saw a rapid expansion in employment. Between 2003 and 2012, the employment share of the services sector increased by one percentage point per annum on average. The employment share of trade services and personal services increased rapidly, and the increase in business services was also significant, albeit from a low level. During this period, the manufacturing employment share plateaued, as previously discussed. 
Figure 7: Decomposition of labour productivity growth, Indonesia

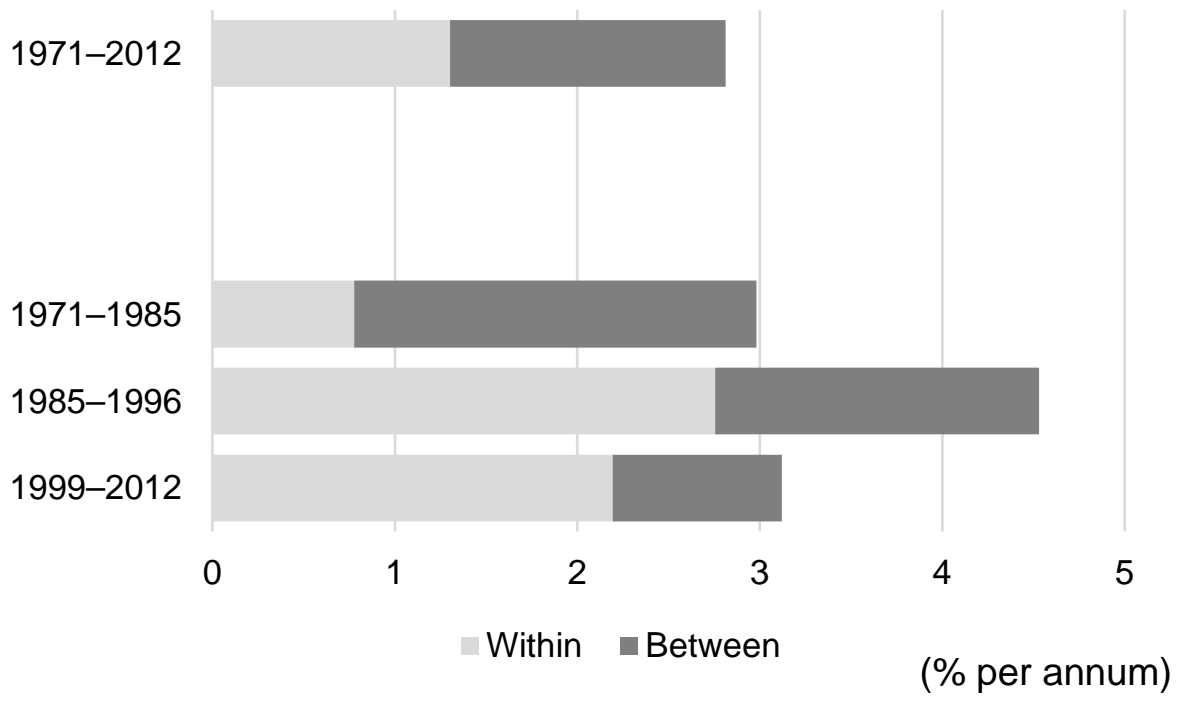

Note: decomposition uses the methodology of McMillan and Rodrik (2011).

Source: authors' illustration based on GGDC 10-Sector Database Version 2015 (Timmer et al. 2015).

The change of the main engine of structural transformation, and more specifically the expansion of the services sector in terms of both value added and employment, has had an important impact on Indonesia's economic growth. Labour productivity growth declined in Indonesia from 4.5 per cent per annum during 1985-96 to 3.1 per cent per annum during 1999-2012. Furthermore, the share of the contribution of structural transformation to labour productivity growth shrank from 39.2 per cent to 29.8 per cent. These trends were caused by changes of the leading sectors in structural transformation.

Figures $8 \mathrm{a}$ and $8 \mathrm{~b}$ show that the manufacturing sector recorded a simultaneous rise in both relative productivity and employment growth during 1971-85 and 1985-96. Construction and utilities and business services also showed a similar trend, yet their employment share was significantly smaller than that of the manufacturing sector. ${ }^{4}$ In comparison, all the economic sectors with higher-thanaverage labour productivity failed to experience a simultaneous rise in relative productivity and employment share in the most recent period (Figure 8c). The manufacturing sector saw both its relative productivity and its employment share decline between 1999 and 2012. The relative labour productivity of construction and utilities and business services also declined during this period. Non-business services saw a rapid expansion of its employment share, but this sector had labour productivity lower than that of the overall economy.

\footnotetext{
${ }^{4}$ In 1996, the employment shares of manufacturing, construction, and business services were 12.9, 4.5, and 1.0 per cent, respectively.
} 
Figure 8: Changes in employment share and relative productivity by sector, Indonesia 8a: 1971 and 1985

Ratio of sectoral productivity to total productivity (log)

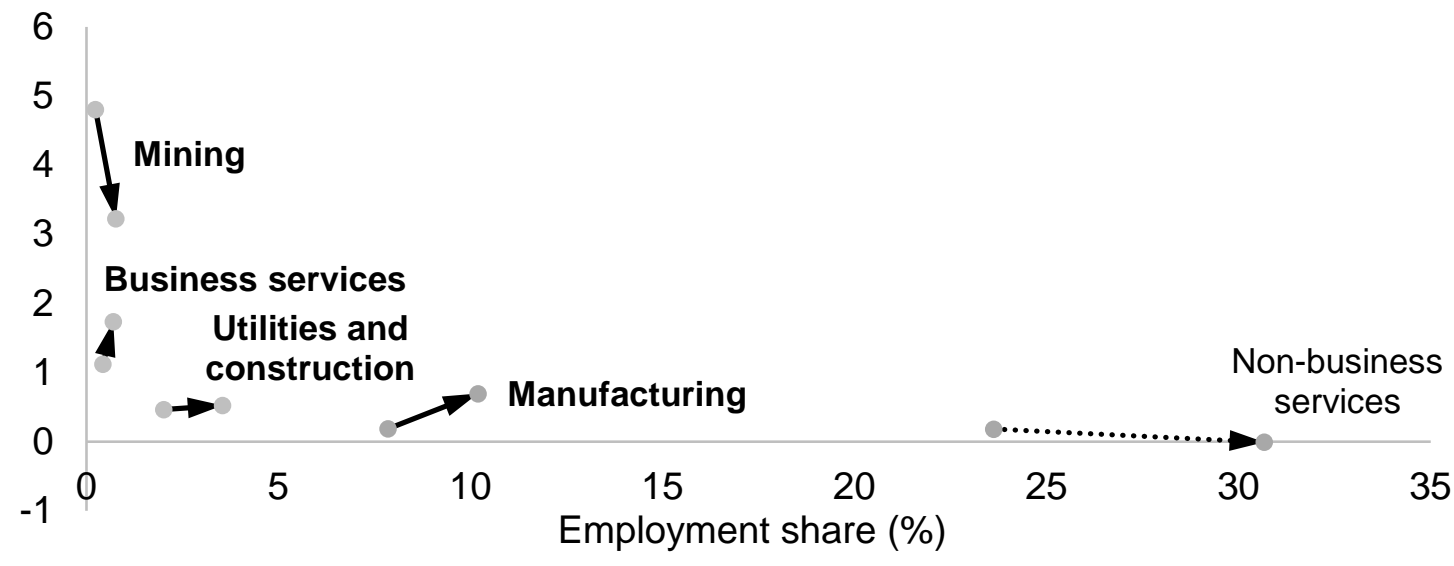

8b: 1985 and 1996

Ratio of sectoral productivity to total productivity (log)

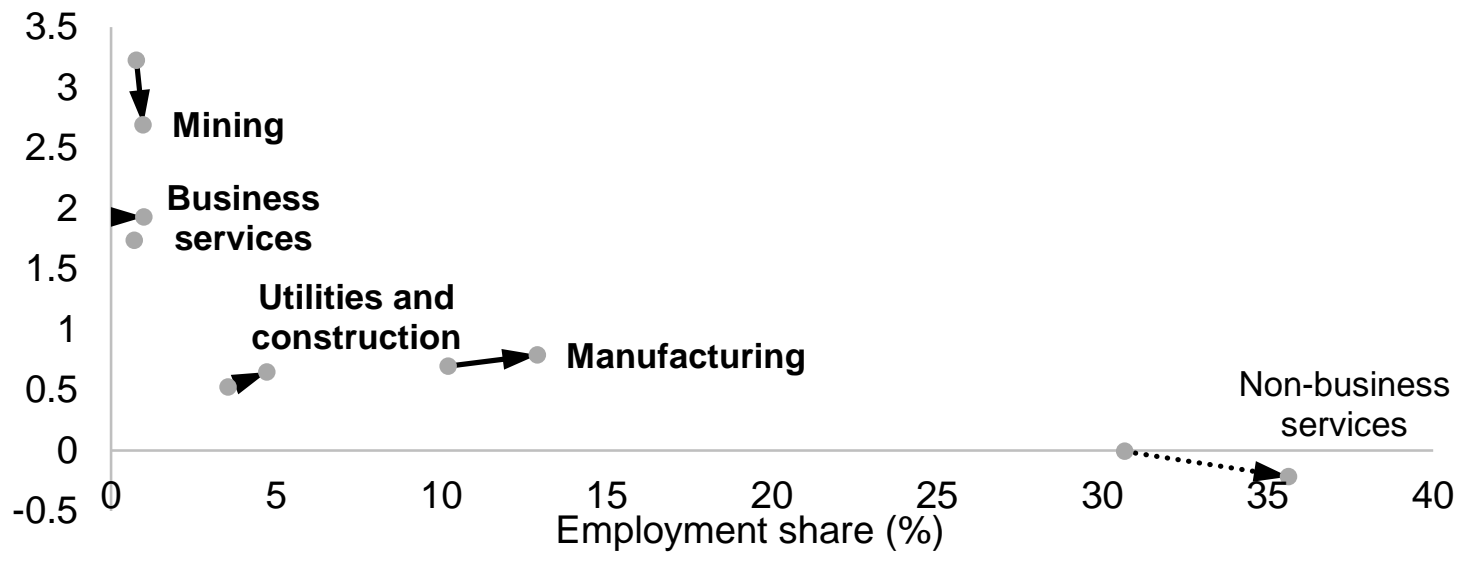

8c: 1999 and 2012

Ratio of sectoral productivity to total productivity (log)

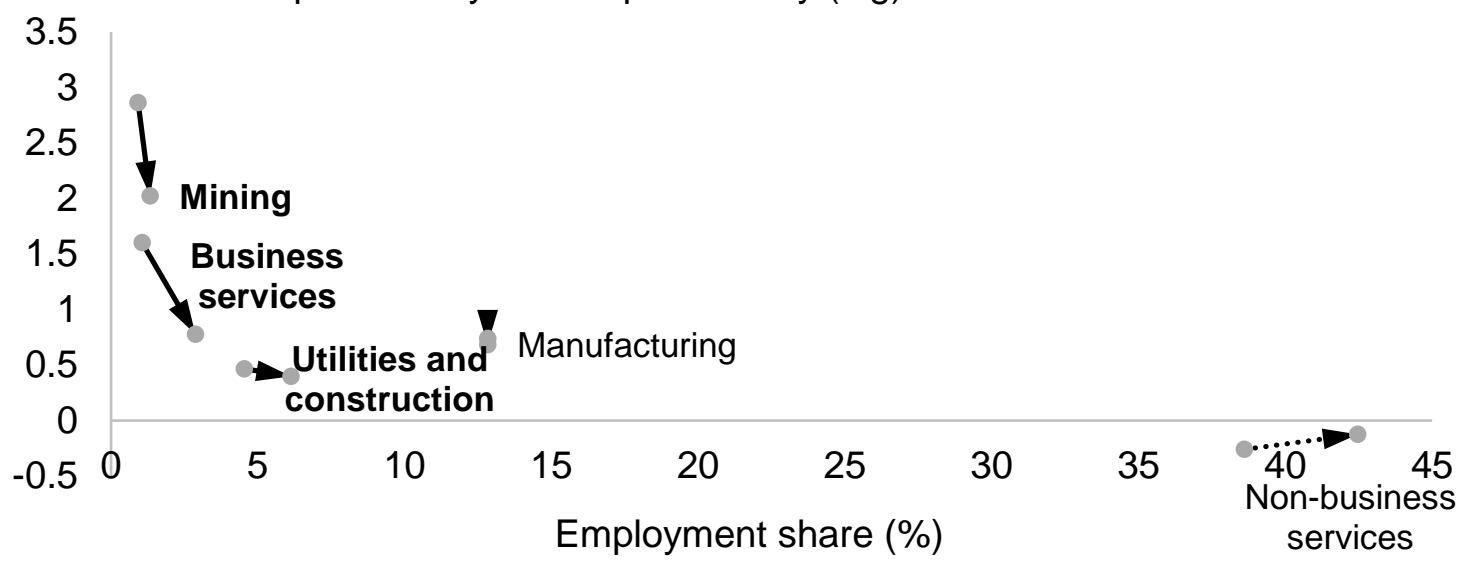

Notes: sectors with labour productivity higher than the economy-wide average labour productivity that experienced an increase in their employment share are in bold.

Source: authors' illustration based on GGDC 10-Sector Database Version 2015 (Timmer et al. 2015). 
In sum, Indonesia's economic growth has lost dynamism compared with the past as the manufacturing sector has stopped playing a central role in structural transformation. From the late 1990s, services drove Indonesia's structural transformation, with the services shares in value added and employment growing rapidly. However, the services subsectors that have led employment generation since the Asian financial crisis have so far displayed weak capacity to drive productivity growth. If the recent trends in structural transformation and productivity growth continue, it would be difficult for Indonesia to follow in the footsteps of the region's leading economies.

\subsection{Inclusive growth: declining poverty amid waves of inequality}

Inequality in Indonesia increased between the mid-1960s and the mid-1970s (Figure 9). This period coincided with a period of slow growth-enhancing structural transformation ('cliff 1' in Figure 2). Van der Eng (2009) suggests that the increase in inequality during this period may have been due to an increase in urban workers' skills premium which was in turn caused by import substitution policies aimed at developing capital-intensive sectors. In contrast, from the mid-1970s, inequality declined for around a decade, and then the Gini coefficient was relatively stable between the end of 1980s and the end of 1990s before suddenly declining in 1999. Low levels of inequality may be due to the positive effects of the government's agricultural development strategy starting to appear from the 1970s. Van der Eng (2009) notes that, thanks to large public expenditure and investment on rural development, agricultural productivity improved along with a large increase in agricultural employment, although the share of agriculture in total employment continued to decline. Another factor that may have caused the decline in inequality is the expansion of labour-intensive manufacturing from the mid-1980s, which generated a substantial number of jobs ('downhill' in Figure 2). In sum, Indonesia avoided Kuznetsian tension between the mid-1970s and the mid1990s, during which time it experienced rapid growth-enhancing structural transformation.

Figure 9: Inequality, Indonesia

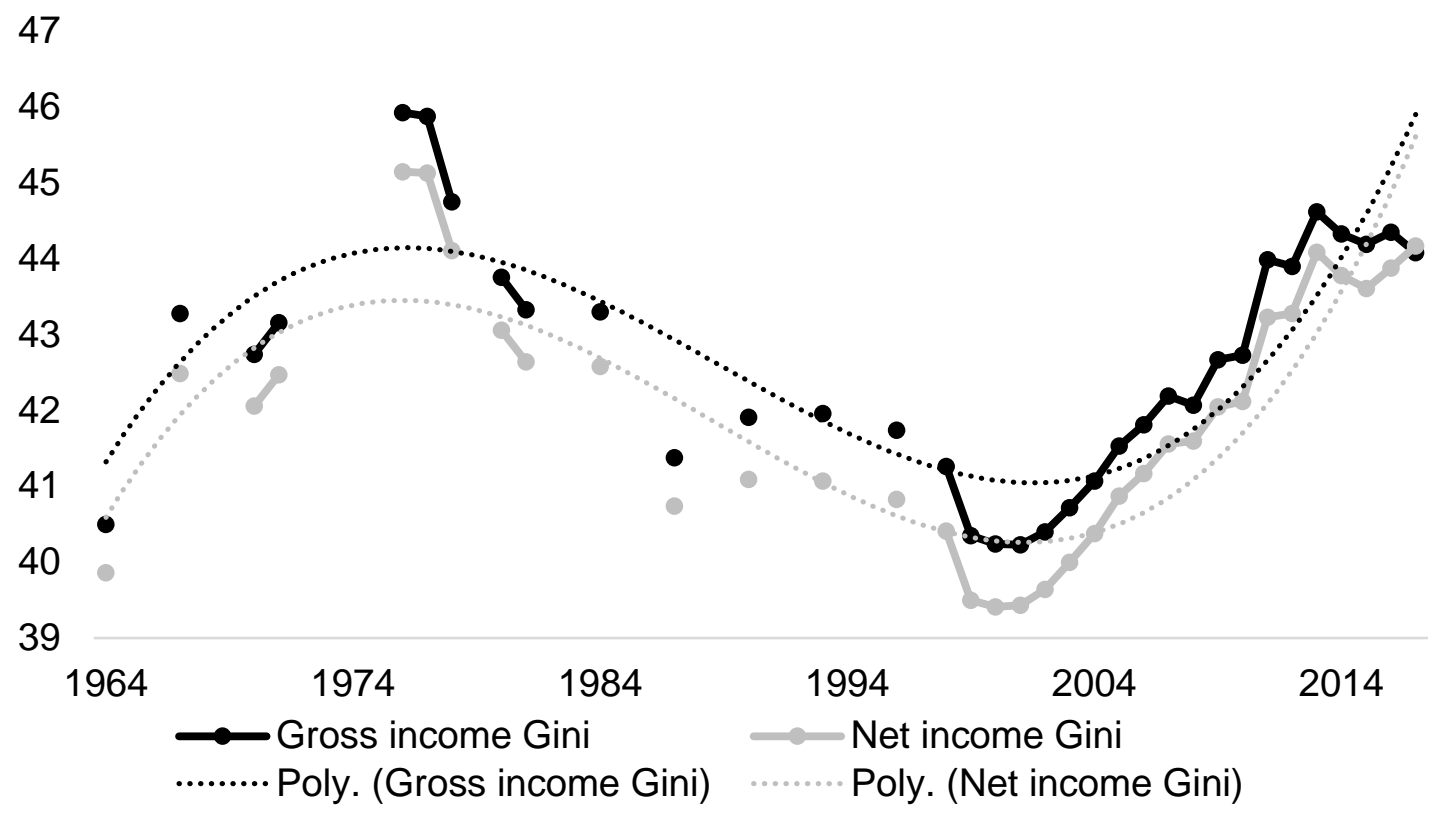

Note: 'Poly.' = 'Polynomial'.

Source: authors' calculations based on WIID (UNU-WIDER).

Figure 9 shows that the increase in inequality from the early 2000s to early 2010s cancelled out much of the decline in income inequality that Indonesia had experienced in the previous two decades. Yusuf et al. (2014: 251-52) suggest that there are three potential reasons for the rise in 
inequality in the post-crisis period. The first two are related to the changing patterns of structural transformation, and weakening manufacturing in particular ('cliff 2 in Figure 3). First, the global commodities boom may have benefited mine owners and richer rural households disproportionately. Second, the combination of stricter market regulations and a lack of formal employment generation may have contributed to higher inequality. There was an increase in severance payments and minimum wages following the Asian financial crisis, while the economic sectors traditionally characterized by high levels of formal employment-such as manufacturing - recorded limited growth compared with the past. In contrast, some economic sectors that employ a large number of informal workers who do not directly benefit from these labour policies expanded quickly. We take a closer look at this issue later in this section. Third, the large proportion of fuel subsidies in fiscal spending may have led to higher inequality. The fuel subsidies which expanded rapidly during this period were regressive, and constrained the fiscal space for increasing social spending. The government increased fuel prices several times to deal with the rise in international oil prices during the second half of the 2000s and the early 2010s, but these measures were insufficient to significantly reduce the share of fuel subsidies in government budget. Additionally, the World Bank (2014c) points out that the rising inequality during this period may be related to (i) richer households' access to assets; (ii) an increasing capital share and a declining labour share in national income; and (iii) a rise in wage inequality driven by a growing gap in returns to education. Finally, Akita (2017) demonstrates that while a decline in urban-rural education disparity contributed to reducing expenditure inequality, the expansion of higher education in urban areas may have been a key causal factor in raising expenditure inequality during the 2000s, as it increased both between educational groups and within the tertiary education group.

Next, we take a look at the trends in poverty. During the 1970s and 1980s, Indonesia experienced a notable poverty reduction. In a survey of studies on diverse poverty measures, Booth (2003: 69) notes that between the late 1960s and the late 1980s, 'whatever the poverty lines used and whatever the means adopted to adjust it for inflation, there seems to be little doubt that the proportion of the population living below the poverty line ... declined in both urban and rural areas'. By taking a closer look at this period and extending the period to the 1990s, Booth (2016: 160-66) argues that economic growth became more pro-poor over time. Observers have noted that despite GDP per capita increasing by almost 70 per cent between 1966 and 1976, poverty reduction was much less dramatic during this decade. One potential reason behind this phenomenon was that the oil revenue translated into higher salaries for public employees with a higher propensity to consume luxury products, rather than for poor households. Also, it is likely that the poorest part of the population benefited little from the government's massive capital investment. In comparison, Indonesia experienced economic growth that was more broad-based between 1976 and 1996. Figure 10 also shows a significant decline in the poverty rates between 1984 and 1996 using the US $\$ 1.90$ a day and $\$ 3.20$ a day (2011 purchasing power parity) poverty lines. The potential drivers of broad-based growth were: (i) the government's rural development programmes; (ii) protection of poverty-related spending during the 1980s; and (iii) structural transformation that was led by labour-intensive sectors such as manufacturing, construction, trade, and transportation (Booth 2016: 165-66). It is also worth noting the government efforts to improve education services from the 1970s onwards, with a particular focus on primary education. Booth (2016: 79) notes that the primary school participation rate increased from 41.4 per cent in 1968 to over 90 per cent in 1993. One notable project was the government's school construction programme between 1973 and 1978, during which more than 61,000 new primary schools were built. Duflo (2001) finds significantly positive effects of this programme on beneficiaries' number of years in education and wages, and suggests that the programme had a larger impact in high-poverty provinces.

Indonesia experienced a sudden increase in the poverty rate during the crisis period of the late 1990s. After a sudden increase towards the end of the 1990s, Indonesia's poverty rates began to 
decline again. The poverty rate at the US $\$ 1.90$ poverty line declined rapidly from 66.6 per cent in 1998 to 9.4 per cent in 2014 and the poverty rate at the US\$3.20 poverty line from 90.2 per cent to 37.9 per cent. ${ }^{5}$ This rapid decline in poverty was despite Indonesia's structural transformation losing dynamism and its overall economic growth slowing down during this period compared with the period before the Asian financial crisis. Figure 11 shows the growth elasticity of poverty using the US $\$ 1.90$ and US $\$ 3.20$ poverty lines. The elasticity is calculated using GDP growth rates and GDP per capita growth rates, and also percentage changes and percentage-point changes in poverty rates. Comparing 1987-96 and 2004-13, Figure 11 demonstrates that the power of economic growth to reduce poverty was stronger in the latter period according to six out of eight indicators. How can we explain this phenomenon? Suryahadi et al. (2012) compare the effects on poverty reduction of growth in value added in urban industry, urban services, rural agriculture, and rural services for 1984-96 and 2002-08. This research also finds an increase in growth elasticities to poverty in the latter period. It demonstrates that urban services, followed by rural services, had the greatest effect on both rural and urban poverty reduction, and that the effect became stronger in the latter period. Taking the growth of sectoral value added into account, the study finds that urban and rural services contributed to 86 per cent of rural poverty reduction and 96 per cent of urban poverty reduction in 2002-08.

Figure 10: Poverty rate, Indonesia

(\%)

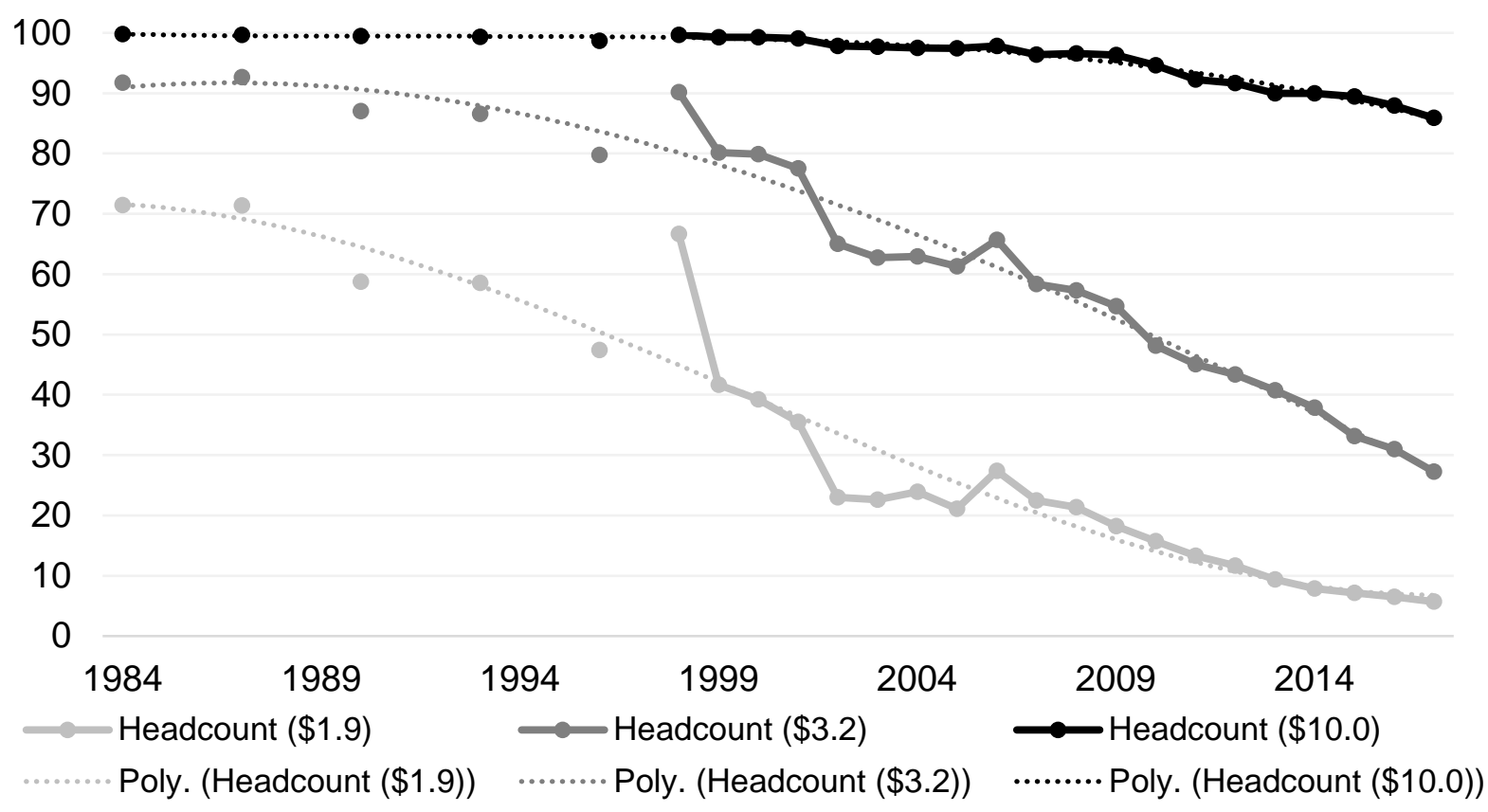

Note: 'Poly.' = 'Polynomial'.

Source: authors' illustration based on Povcalnet Version March 2019 (World Bank 2019a).

\footnotetext{
${ }^{5}$ The declining trend was fairly resilient except in 2006, when the US $\$ 1.90$ poverty rate increased from 21.1 per cent in 2005 to 27.4 per cent in 2006 and the US\$3.20 poverty rate from 61.3 to 65.7 per cent. A sudden rise in poverty rates in 2006 was probably due to a large increase in the rice price-by 33 per cent between February 2005 and March 2006 - which was in turn caused by the ban on rice imports (World Bank 2006: 26). McCulloch (2008) demonstrates that a majority of households in Indonesia, rural and urban, are net consumers of rice and therefore were negatively affected by higher rice prices.
} 
Figure 11: Growth elasticities of poverty, Indonesia

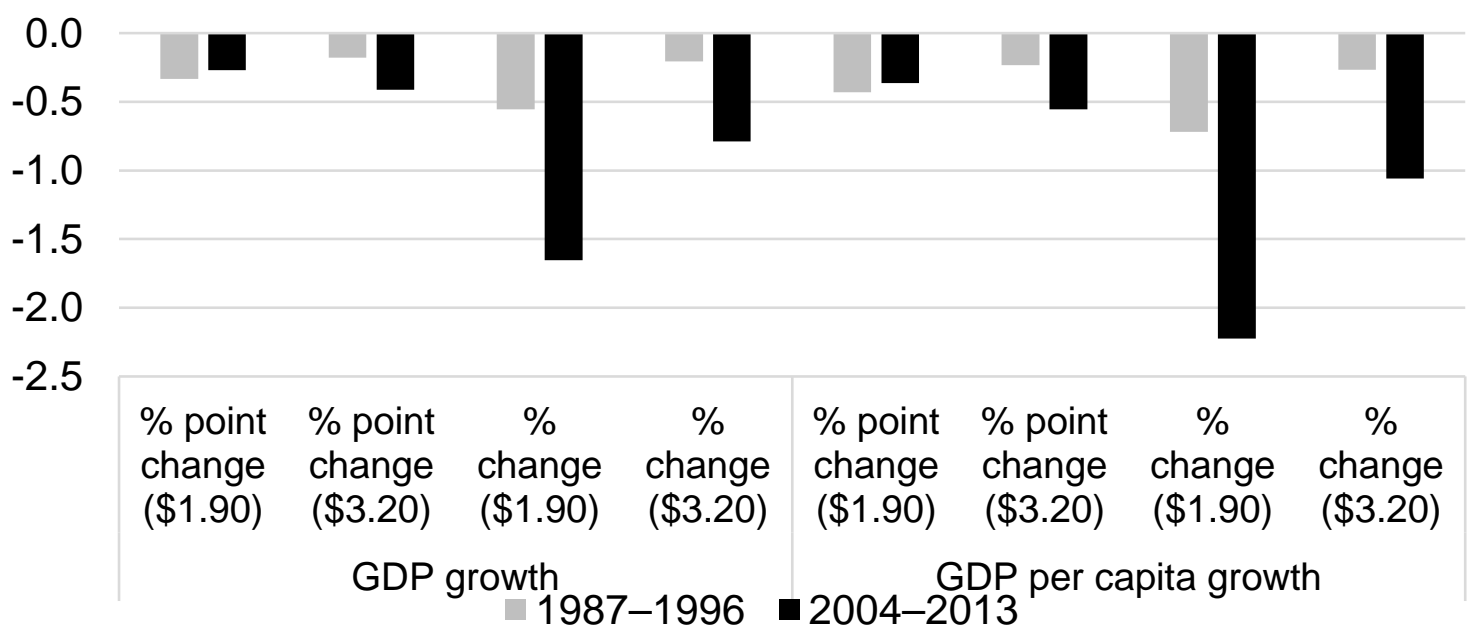

Source: authors' illustration based on Povcalnet Version March 2019 (World Bank 2019a) and World Development Indicators, June 2019 version (World Bank 2019b).

While the services-centred structural transformation after the Asian financial crisis led to slower economic and productivity growth and coincided with a rise in inequality, there is no evidence to suggest that the power of economic growth to reduce poverty weakened. However, it is important to highlight that the poverty rates at higher thresholds have been stubbornly high. Figure 10 shows that the poverty rate using the US $\$ 10.00$ threshold has only declined slightly in the past two decades, and was recorded at 85.9 per cent in 2017. Moreover, if medium-paced growth and high inequality continue, then poverty reduction is expected to be much more challenging.

Lastly, this section examines the composition of formal and informal employment in Indonesia between 1989 and 2010. ${ }^{6}$ The evidence shows that a significant number of workers in developing countries have left the agricultural sector to carry out small-scale informal activities in nonagricultural sectors. Some countries have even seen labour shift from manufacturing to informal services, which is a serious concern in terms of productivity (Jütting and de Laiglesia 2009; McMillan et al. 2014; World Bank 2012, 2014a). Furthermore, workers' job security and social safety net in the informal sectors tend to be weak. The International Labour Organization (ILO 2017) points out that informal jobs are characterized by a 'lack of protection in the event of nonpayment of wages, compulsory overtime or extra shifts, lay-offs without notice or compensation, unsafe working conditions and the absence of social benefits such as pensions, sick pay and health insurance'. For these reasons, informal workers are not only vulnerable to shocks, but are also a precarious group that struggles to plan for the future.

Figure 12 shows that the formal employment share expanded rapidly between 1989 and 1997, during which time a large number of workers left the agricultural sector and entered the modern

\footnotetext{
${ }^{6}$ Because of the changes in the survey methodology, the data before and after 2000 cannot be directly compared. A sudden decline in the formal employment share in 2001, as shown in Figure 11, is mainly due to the methodological change; see the notes to Figure 11 for more details. Moreover, the authors recognize that the crude categories of formal and informal employment have limitations and the definitions of formal and informal employment vary across different contexts. For a detailed analysis of the issues relating to Indonesia's employment data and formal and informal employment categories, see World Bank (2010).
} 
sector. ${ }^{7}$ Figure 13 shows that the share of formal employment in the industrial and services sectors in total employment increased rapidly. Their shares increased by 50 per cent ( 5.0 percentage points) and 36 per cent (6.2 percentage points), respectively, between 1989 and 1997. Then, between 1997 and 2000, the formal employment share declined as the Asian financial crisis halted Indonesia's structural transformation. This pattern was caused mainly by the employment share of agriculture, a sector with the lowest 'within-sector' formal employment share, suddenly increasing. Figure 13 shows that the share of agricultural informal employment in total employment increased from 35 per cent to 39 per cent, while the formal employment share of industry and services declined from 39 per cent to 35 per cent. The formal employment share in the economy declined further between 2001 and 2003 and only began to recover from the mid-2000s onwards, as the declining trend of the agricultural employment share, or structural transformation, resumed. Between 2005 and 2010, the increase in the formal employment share was driven by the services sector. The share of services' formal employment in total employment increased from 20 per cent in 2002 to 25 per cent in 2010. However, the share of industry's formal employment declined slightly from 13 per cent to 12 per cent. This contrasts with the period before the Asian financial crisis, when the industrial sector was an important driver of formal job creation. While the overall increase in formal employment share during services-led economic growth is a positive sign, this increase could have been larger if Indonesia's manufacturing sector had continued to play an important role in structural transformation, as the sector has a high within-sector formal employment share. ${ }^{8}$

Figure 12: Share of formal sector employment, Indonesia

(\% of total employment)

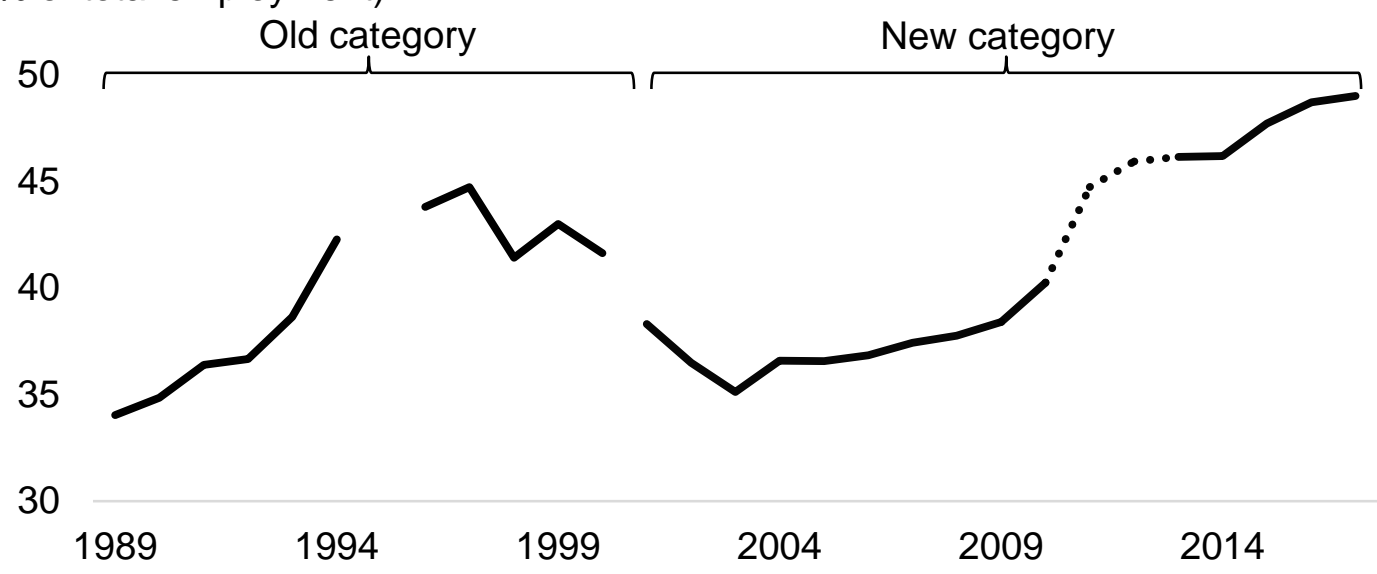

Notes: (i) simplified definition of formal employment is used. Formal workers are defined as employers and employees in the agricultural sector and employers, employees, and self-employed with temporary workers in the non-agricultural sector. Informal workers are defined as family workers, self-employed, and self-employed with temporary workers in the agricultural sector and family workers and self-employed in the non-agricultural sector. From 2001, a new category of 'casual workers' was added to the survey; these workers in both agricultural and non-agricultural sectors are classified as informal workers. (ii) Data before and after 2001 are not directly comparable because surveys in these two periods use different categories. (iii) Data for 2011-13 are backtracked data and data before and after this period are not directly comparable because of the changes in the survey methodology. (iv) There are no data for 1995. (v) Surveys were conducted twice a year from 2005. August survey data are used for the period 2005-17.

Source: authors' illustration based on BPS (2019).

\footnotetext{
${ }^{7}$ Changes in the share of a sector's formal employment in total employment depend on changes in that sector's employment share in total employment and changes in the formal employment share within that sector. For a detailed analysis of changes in these two components, see Kim et al. (2017).

${ }^{8}$ In 2005, the formal employment share within manufacturing was 77 per cent and those within services and agriculture were 54 and 8 per cent, respectively.
} 
Another consequence of the changing characteristics of structural transformation since the Asian financial crisis is that the expansion of formal employment is no longer led by sectors with high labour productivity. ${ }^{9}$ Figure 14 shows that between 1989 and 1997, the sectors with above-average labour productivity were important contributors to the expansion of the formal employment share. The share of these sectors' formal employment in total employment increased from 12 per cent in 1989 to 18 per cent in 1997. In contrast, this share was stuck at around 15-16 per cent between 2003 and 2010, while the share of low-productivity sectors' formal employment in total employment expanded from 16 per cent to 22 per cent. These recent patterns suggest that one factor that potentially contributed to inclusive growth before the Asian financial crisis-namely, the expansion of high-productivity formal jobs-has weakened since the Asian financial crisis.

Figure 13: Employment composition by sector and worker status, Indonesia

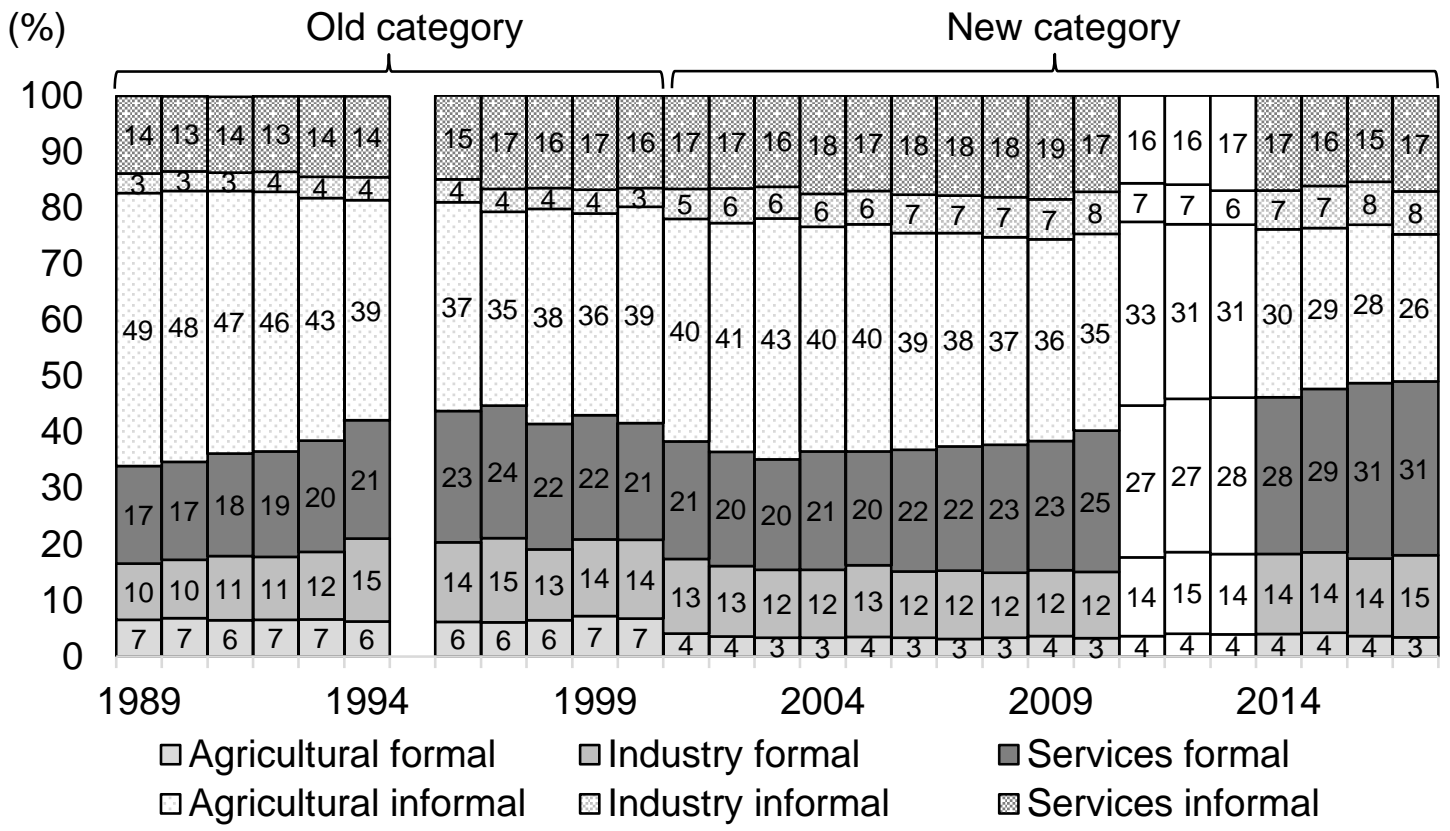

Notes: see notes to Figure 12.

Source: authors' illustration based on BPS (2019).

\footnotetext{
${ }^{9}$ For simplicity, average labour productivity in 2017 is used to categorize sectors with high (above-average) and low (below-average) productivity.
} 
Figure 14: Employment composition by productivity and worker status, Indonesia

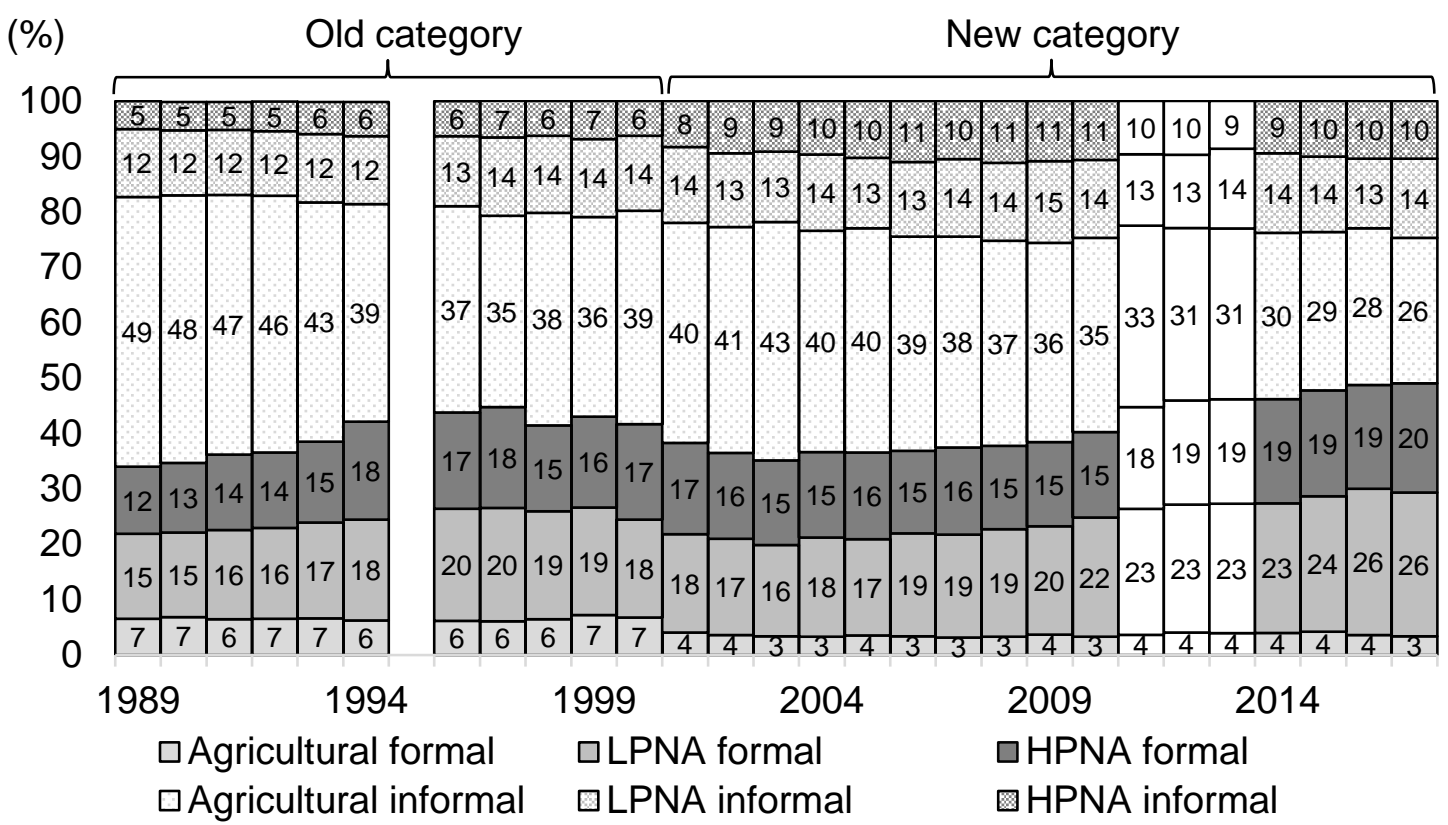

Notes: see notes to Figure 12. LPNA stands for 'low-productivity non-agricultural sectors', HPNA for 'highproductivity non-agricultural sectors'. If a sector had labour productivity above the economy-wide productivity level, it is classified as HPNA, otherwise as LPNA.

Source: authors' illustration based on BPS (2019).

\section{$5 \quad$ Development challenges and policies under democracy}

\subsection{Political economy and the developer's dilemma}

Indonesia's political economy, and more precisely the politics of economic and social policymaking, has changed markedly since the late 1990s when Indonesia became a democracy. As Section 4 discussed, the Indonesian economy experienced rapid industrialization during the two decades from the mid-1970s onwards. During this period, the level of state involvement in driving structural transformation changed over time. In the second half of the 1960s, the Soeharto government faced the challenge of escaping the economic crisis and therefore decided to open up the economy in line with the demands of international creditors. Along with economic stabilization measures, liberalization was perceived as necessary to attract foreign capital. After several years, however, the government decidedly turned away from liberalization and pursued import substitution industrialization. From the 1970s, nationalist and anti-foreign sentiment strengthened, especially among indigenous capitalists, and the state's economic power strengthened with the oil boom. In this situation, the state became the pivotal actor in shaping the patterns of structural transformation-directly, through its state enterprises, and indirectly, by providing credit, contracts, and concessions to private companies. The economic policy stance took yet another turn in the 1980s when the end of the oil boom weakened the government's capacity to directly drive industrialization. The decade from the mid-1980s onwards was characterized by selective deregulation and liberalization with the aim of attracting foreign investment and stimulate exports.

These shifts in economic policy stance during Soeharto's three decades in power were influenced by the changing economic situation, but it is also important to note that Soeharto's authoritarian regime faced limited domestic political resistance to its shifting the stance. Also, whatever economic policy stance the government took, the politico-bureaucrats and the oligarchs-mainly 
Chinese Indonesian — close to the presidential palace benefited handsomely over this period. Of course, and as the preceding sections highlight, the regime did not overlook the importance of improving Indonesians' living standards, and it therefore strengthened the provision of public services to a certain extent (Booth 2016; Hill 1996; Robison 1986). Yet this period was characterized by relative ease, as the government shifted fiscal resources from consumption to investment and provided privileges to certain actors when it felt this to be necessary, compared with the recent democratic era.

When the democratic era began in Indonesia, the government initially focused on improving social protection provision and then gradually strengthened state activism with the aim of reviving growth-enhancing structural transformation. However, the process of strengthening state economic activism has been complex. Under the democratic political system, there has been strong competition among stakeholders who prioritize different development goals. The government's annual fiscal allocation has also been influenced by the political schedule. For example, there was fierce resistance when the government tried to continue injecting large amounts of capital into state enterprises during the second half of the 2010s in order to accelerate development projects. The opposition in the parliament argued for greater social spending and subsidies. Such resistance limited the government's ability to strengthen state enterprises. The fiscal budget then increasingly focused on social spending in the second half of the administration, ahead of the presidential election (Kim 2019a). Under the current system, whenever there are opportunities for the government to expand discretionary spending, the administration is pulled in different directions by stakeholders prioritizing diverse development programmes. The growth-focused stakeholders point out the detrimental effects of lethargic structural transformation, while the equity-focused stakeholders emphasize Indonesia's low social spending compared with that of other middleincome countries. The precise balance of fiscal spending between these two broad goals will depend on voters' views on development priorities and also on the political power of different stakeholders in the policy process. Also, the political difficulties of deciding whom to target in the provision of social protection and subsidies will remain a key issue in designing Indonesia's development strategy.

A more fundamental problem exists in Indonesia that limits the degree of state activism in dealing with development challenges. Indonesia's fiscal spending is low, as a percentage of GDP or in per capita terms, in major development areas such as infrastructure, health, and education. ${ }^{10}$ The problem is not necessarily the small share of development spending in the total budget but the size of the fiscal budget itself. The government is legally required to allocate at least 20 per cent and 5 per cent of the total budget to education and health, respectively. From the mid-2010s, it has substantially reduced fuel subsidies and increased infrastructure investment. While further restructuring of the budget composition could make government policies more developmental, the key problem that constrains state activism is Indonesia's weak fiscal capacity. Although Indonesia's government debt-GDP ratio has stabilized around a relatively low level of 30 per cent, the government cannot substantially expand development spending without larger fiscal revenues due to the fiscal rule that caps its annual fiscal deficits at 3 per cent. Given these circumstances, the ability to pursue development policies depends on how much the government can expand fiscal revenues. Figure 15 shows that Indonesia's government revenue and expenditure as a share of GDP are among the lowest in major developing countries, and are also low considering the country's income level. Without substantially expanding fiscal revenue, the Indonesian

\footnotetext{
${ }^{10}$ See World Bank (2013) on infrastructure spending, World Bank (2014a) on health spending, and World Bank (2018) on education spending.
} 
government will have limited resources with which to stimulate growth-enhancing structural transformation and inclusive growth.

Figure 15: General government revenue and expenditure, major emerging and developing economies
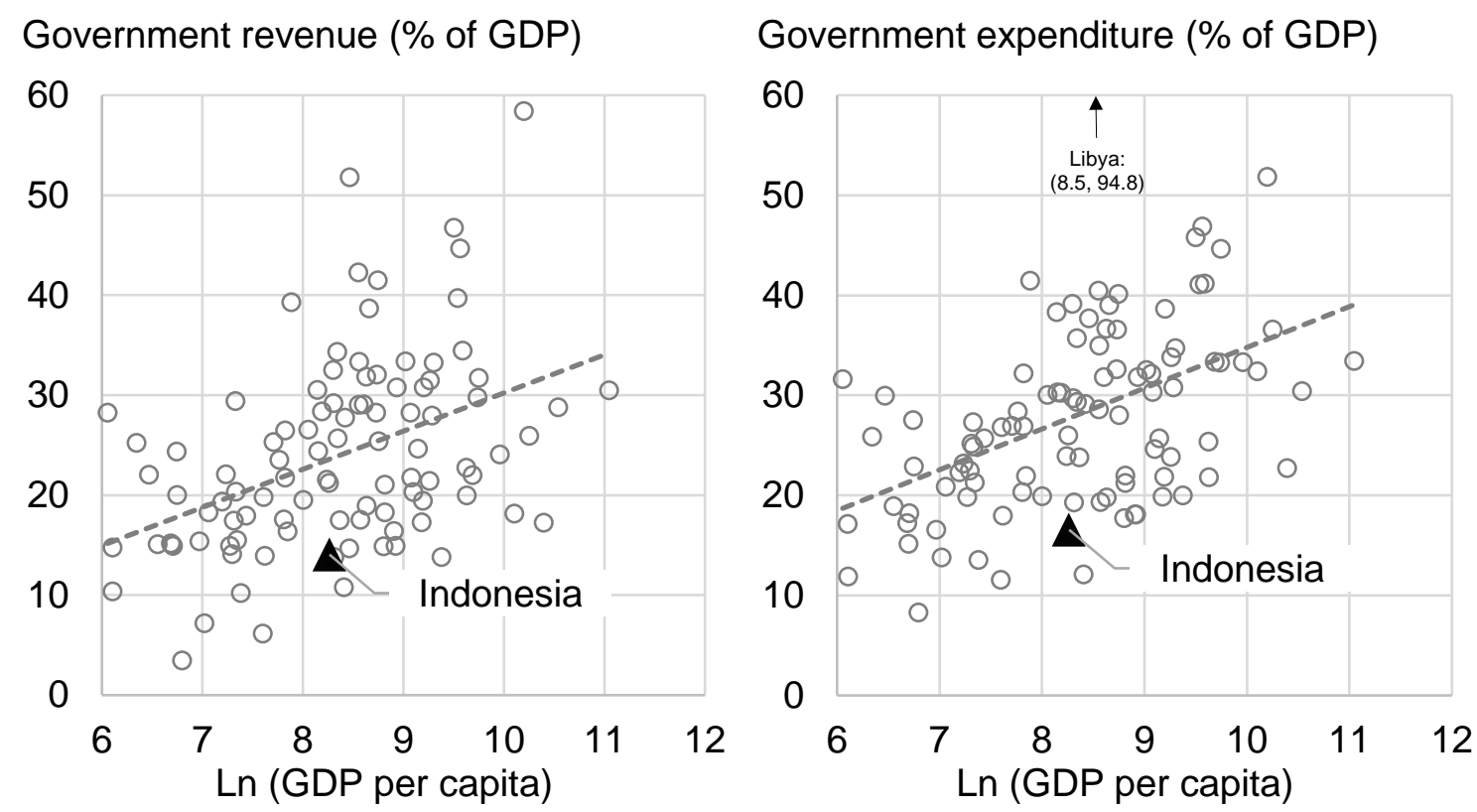

Note: 100 largest emerging and developing countries in terms of GDP in 2017.

Source: authors' illustration based on IMF (2019).

Finally, it is important to highlight the continued influence of the oligarchs, many of whom strove during the Soeharto era, survived the Asian crisis, and have flourished over the past two decades. Robison and Hadiz (2017) argue that the oligarchs, who hold massive material wealth, continue to influence Indonesia's economic policies and how government resources are allocated. They suggest that the recent economic protectionism has been the government's response to oligarchs' demands. From this viewpoint, the government's goal is understood as prioritizing the growth of oligarchs' wealth rather than providing public goods and stimulating national development. The composition of Jokowi's 'rainbow cabinet' also suggests that the government's resources for economic development are vulnerable, as ministers from diverse political factions try to benefit their vested interests (The Economist 2019). At the same time, the influence of the demands of median voters on the government's development strategy cannot be overlooked in a democratic Indonesia which holds regular elections. Considering these issues, the future trajectory of Indonesia's structural transformation and inclusive growth will depend on whether and how the government aligns the interests of oligarchs, political elites, and the voters.

The rest of this section reviews some of the major policies that the government has adopted to fix the patterns of structural transformation and inclusive growth over the past decade within this changed policymaking environment.

\subsection{Structural transformation policies}

In this section, we first extend the analysis of structural transformation to the most recent period using the data on value added in constant 2010 prices and employment from Indonesia's central statistics office. We find the following trends during 2010-17. First, structural transformation has continued, with the agricultural sector's value added share declining from 14.3 per cent in 2010 to 13.2 per cent in 2017 and its employment share declining from 38.3 per cent to 29.7 per cent. 
Second, the stagnation of the manufacturing value added and employment shares, or 'stalled industrialization', has continued. The value added and employment shares averaged 22.3 per cent and 13.4 per cent, respectively, between 2010 and 2017, with no clear trend. The relative productivity of the manufacturing sector continued to decline in this period. Third, services-led structural transformation has continued, with the value added share increasing from 41.8 per cent in 2010 to 45.0 per cent in 2017 and the employment share from 42.3 per cent to 48.1 per cent. This expansion, again, was led by services subsectors with relatively low productivity, namely trade services and personal services. These two subsectors accounted for four-fifths of the total increase in the services employment share between 2010 and 2017.

From the late 2000s onwards, the Indonesian government began to strengthen state economic activism with the aim of stimulating structural transformation. The aim has been to move away from 'stalled industrialization' towards 'upgrading industrialization'. The key aspects of Indonesia's economic development strategy during the 2010s are as follows: (i) protecting lagging sectors; (ii) liberalizing certain sectors to attract investment; and (iii) strengthening state participation in the economy to deal with market failures. This subsection takes a look at each of these approaches.

First, the government has adopted various non-tariff measures and investment regulations to support or protect Indonesia's lagging sectors. For example, after commodity prices began to fall, the government banned exports of certain unprocessed minerals in 2014 and stipulated that miners build processing and refining facilities in Indonesia. The aim was to develop downstream industries and add value to mining products. The government has also implemented a policy requiring mining companies to reduce foreign shareholding to 49 per cent over time (PwC Indonesia 2018a). Furthermore, it has adopted local content rules to stimulate domestic production in sectors such as smartphone manufacturing and software development (Hardum and Halim 2016).

Second, while strengthening regulations in certain sectors, the government has also implemented liberalization measures in others in order to attract private investment. Between September 2015 and November 2018, the government adopted 16 sets of stimulus packages which mostly contained plans to open up the Indonesian economy and streamline bureaucratic procedures in order to accelerate the investment process (Indonesia Investments 2018). In particular, the tenth and the sixteenth economic stimulus packages included notable investment liberalization measures. The package in 2016 relaxed investment regulations on 101 business sectors and the package in 2018 proposed regulatory relaxation in 87 business sectors (PwC Indonesia 2018b).

Third, the government started to directly lead infrastructure development during the second half of the 2010s. In the previous decade, Indonesia's infrastructure development strategy was designed with the expectation that the private sector would actively participate in investment and construction. However, this strategy had only limited success, as the private sector was concerned about regulatory and business uncertainties. Acknowledging that institutional reform takes time and is often politically difficult, the Indonesian government decided to act as the driver of infrastructure development from the mid-2010s onwards. The Indonesian government increased infrastructure investment significantly during the second half of the 2010s after cutting the fuel subsidies that had burdened the fiscal budget of previous administrations. It also actively mobilized state-owned enterprises to invest in and construct infrastructure and expanded development financial institutions_-so-called development banks—to finance projects (Kim 2019b; World Bank 2017a).

In sum, the pattern of structural transformation during the 2010s has not changed much from that of the previous decade. Therefore, medium-paced economic growth has continued. The 
Indonesian economy is yet to see the effects of the government's strategy to improve the overall pattern of structural transformation or to achieve 'upgrading industrialization'.

\subsection{Inclusive growth policies}

Around the mid-2010s, there was a meaningful change in Indonesia's inequality trend. The rising trend in inequality ended in the early 2010s and the Gini coefficient stabilized during the first half of the 2010s. The data between 2013 and 2017 suggest that the trend may even have reversed: the gross income Gini coefficients declined by 0.54 points (Figure 9). Poverty reduction has continued (Figure 10), and considering the recent pace of this, it would be reasonable to expect Indonesia to be close to eradicating extreme poverty at the US $\$ 1.90$ poverty line by 2030 . Yet reducing poverty rates at higher thresholds would be most challenging, especially if inequality stays high. In formal and informal employment composition, a pattern similar to that of the previous period has continued. The services sector led the expansion of the formal employment share in total employment (Figures 12 and 13). A positive sign is that Indonesia has not experienced the rising level of job informality that is increasingly a concern for other developing countries going through services-led economic growth. However, the expansion of formal jobs has been driven by subsectors with relatively low productivity, and therefore a future challenge is to create a large number of formal jobs in high-productivity sectors (Figure 14). This point, again, highlights why policy makers are searching for ways to invigorate the manufacturing sector.

The government has also been strengthening its role in stimulating inclusive growth. The public policies for accelerating poverty reduction and dealing with inequality have involved (i) targeted social assistance programmes; (ii) universal health coverage; and (iii) projects to reduce regional disparity. This subsection provides an overview of these policies.

First, an array of social assistance programmes have been implemented since the 2000s. As the public debt position began to stabilize in the mid-2000s, the government started to expand fiscal spending on social assistance programmes. On annual average, the size of central government expenditure (in real terms) on social assistance programmes increased from 29.7 trillion rupiah in 2005-09, to 37.2 trillion rupiah in 2010-14, to 55.5 trillion rupiah in 2015-16 (Figure 16). Steps were taken to shrink large untargeted subsidies during the 2010s, and the saved fiscal resources were redirected to several targeted programmes (World Bank 2017b). Between the mid-2000s and the mid-2010s, the relative importance of programmes of health insurance for the poor, cash transfer for poor and at-risk students, and conditional cash transfer strengthened in the fiscal budget while that of the programme of unconditional cash transfer weakened. The subsidized rice programme has consistently received a large share of total spending on social assistance programmes. 
Figure 16: Central government expenditure on social assistance programmes, Indonesia

60

50

40

30

20

10

0 $\square$ Others

๑Unconditional cash transfer

$\square$ Conditional cash transfer

$\square$ Cash transfer for poor and at risk students

$\square$ Subsidized rice

- Health insurance for the poor

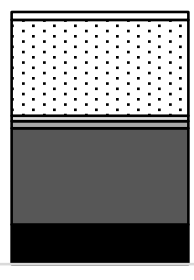

2005-2009

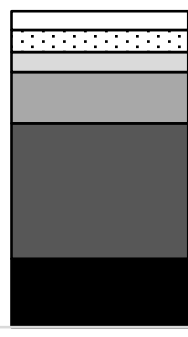

2010-2014

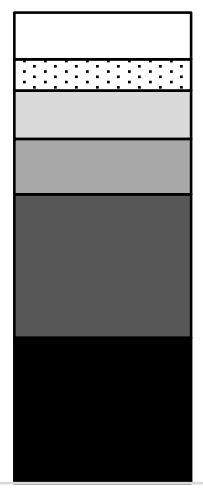

2015-2016

Notes: figures in trillion rupiah, real 2010 prices, annual average.

Source: authors' illustration based on World Bank (2017b).

Second, the Indonesian government has been trying to support the poor by expanding health coverage. The government institutionalized the single-payer insurance administrator and the unified national health insurance programme in 2014 and set a goal to expand coverage to the entire population by 2019 (Pisani et al. 2015; World Bank 2014b). This goal led to a large increase in government spending on the programme of health insurance for the poor, as shown in Figure 16 (World Bank 2015).

Third, many infrastructure projects that were implemented during the second half of the 2010s were aimed at solving regional inequality. While criticism continues that infrastructure development is Java-centric, the government has also focused on infrastructure projects outside Java, such as the Trans-Sumatra toll road. Also, it has implemented various programmes to reduce the price gap between regions. Programmes such as 'One Fuel Price', 'Bright Indonesia', and 'Pioneering Shipping' have been adopted to reduce the price of essential consumption goods in remote areas of the archipelago.

Indonesia's future inclusive growth will depend on how rapidly government spending on social programmes can expand, and on these programmes' ability to target the poor. Significant improvements seem necessary, as the ability of Indonesia's fiscal policy to reduce inequality in the early 2010s lagged behind that of many developing countries (World Bank 2016). Also, whether the Indonesian economy will experience broad-based, growth-enhancing structural transformation will determine inequality and poverty trends. Dynamic structural transformation that creates a large number of formal jobs in high-productivity sectors could contribute to bringing down the poverty rates at higher thresholds that have shown a relatively smaller decline in recent decades.

\subsection{Looking ahead}

We end this section by highlighting some of the key issues that are expected to influence the future trajectory of Indonesia's structural transformation and inclusive growth. First, as China tries to shift towards 'advanced industrialization' that relies more on capital-intensive, as opposed to labour-intensive, manufacturing sectors, South-East Asian economies, including Indonesia, must compete to attract the bulk of the manufacturing investment that is seeking low-cost production bases. Several countries in the region that have experienced 'stalled industrialization' in recent 
decades view this as an opportunity to stimulate growth-enhancing structural transformation. The most practical option to achieve this over a short period may be to join the global value chain (GVC). However, the Indonesian government should remember that the effects on sustainable industrialization and inclusive growth of relying on the GVC are uncertain. Therefore, it should actively negotiate terms with multinational companies in the short term while seeking ways to build strong domestic industries in the longer term. Second, the Indonesian government views ruralurban inequality as a structural problem that small-scale policies will struggle to solve. Therefore, it has floated the idea of relocating the capital city from Java to Kalimantan. While the motivation seems to be clear, there are many uncertainties regarding the actual effects on inequality, as Jakarta would remain the economic centre of the country for decades to come. Research on these issues will improve our understanding of the future patterns of structural transformation and inclusive growth in Indonesia.

\section{Conclusions}

Its remarkable performance in structural transformation and inclusive growth between the 1970s and the first half of the 1990s made Indonesia one of the eight high-performing Asian economies that the World Bank (1993) touted as miracle. For two decades from the mid-1970s onwards, Indonesia's growth-enhancing structural transformation was dynamic, with the manufacturing sector driving productivity and employment growth. The poverty rate declined significantly, with declining or low and stable inequality. In comparison, the post-Asian financial crisis period saw structural transformation losing dynamism, with relatively low-productivity services subsectors soaking up many workers. The inequality level increased until the mid-2010s, returning to a level similar to that recorded in the mid-1970s. Poverty has declined notably, but it could have fallen faster if inequality had not risen as rapidly as it did during the 2000s.

In response to the recent trends in structural transformation and inclusive growth, the Indonesian government began to take a stronger role in tackling development challenges during the 2010s. The ultimate goal is to turn the structural transformation and inequality trends of the past two decades, which can be described as a 'cliff, into a 'downhill' similar to the one that Indonesia experienced between the mid-1970s and the mid-1990s (Figure 3). While an increase in the formal employment share is a positive development, Indonesia now needs to consider the quality of formal job creation. In other words, the government needs a strategy to create more formal jobs through the expansion of high-productivity activities. While this strategy is important in terms of structural transformation and inclusive growth, it could also have a positive effect on raising the government revenue that is much needed in order to pursue state activist policies.

The government has strengthened or weakened economic regulations depending on sectoral needs, and has recently begun to lead projects aimed at fixing market failures. It is also expanding social assistance programmes and making efforts to improve the targeting of these programmes. However, there are notable differences in recent state activism compared with the period before the Asian financial crisis. The policy process through which the government designs and implements development policies has changed with democratization. Improvements in accountability and transparency compared with the authoritarian era are a positive sign, yet the government currently has little room to manoeuvre because of voters' diverse demands, political contestation, and limited fiscal resources. In the case of Indonesia, a critical factor that will determine the government's ability to stimulate structural transformation and inclusive growth will be the availability of funding for development projects. An immediate challenge is to find ways to expand government revenues. The active mobilization and effective management of state 
development financiers, which have grown rapidly in recent years (Kim 2019b), may be a way to support the government to finance development spending in a sustainable manner.

\section{References}

Akita, R. (2017). 'Educational Expansion and the Role of Education in Expenditure Inequality in Indonesia since the 1997 Financial Crisis'. Social Indicators Research, 130(3): 1,165-86.

Aswicahyono, H., C. Basri, and H. Hill (2000). 'How Not to Industrialise? Indonesia's Automotive Industry’. Bulletin of Indonesian Economic Studies, 36(1): 209-41.

Aswicahyono, H., K. Bird, and H. Hill (1996). 'What Happens to Industrial Structure When Countries Liberalise? Indonesia since the Mid-1980s'. The Journal of Development Studies, 32(3): 340-63.

BPS (Badan Pusat Statistik) (2019). 'Survei Angkatan Kerja Nasional'. Jakarta: BPS. Available at: https://www.bps.go.id/subject/6/tenaga-kerja.html\#subjekViewTab3 (accessed 20 August 2019).

Booth, A. (1993). 'Counting the Poor in Indonesia'. Bulletin of Indonesian Economic Studies, 29(1): 5883.

Booth, A. (2016). Economic Change in Modern Indonesia: Colonial and Post-Colonial Comparisons. Cambridge: Cambridge University Press.

Chua, C. (2008). Chinese Big Business in Indonesia: The State of Capital. London and New York: Routledge.

Duflo, E. (2001). 'Schooling and Labor Market Consequences of School Construction in Indonesia: Evidence from an Unusual Policy Experiment'. The American Economic Review, 91(4): 795-813.

Fane, G. (1999). 'Indonesian Economic Policies and Performance, 1960-98'. The World Economy, 22(5): 651-68.

Feridhanusetyawan, T., and M. Pangestu (2003). 'Indonesian Trade Liberalisation: Estimating the Gains'. Bulletin of Indonesian Economic Studies, 39(1): 51-74.

Fujita, N., and W. James (1997). 'Employment Creation and Manufactured Exports in Indonesia, 1980-90'. Bulletin of Indonesian Economic Studies, 33(1): 103-15.

Fukuoka, Y. (2015). 'Who Brought Down the Dictator? A Critical Reassessment of So-Called "People Power" Revolution in the Philippines and Indonesia'. Pacific Review, 28(3): 411-33.

Hardum, S., and D. Halim (2016). 'New Local Content Rule for Smartphones Paves Way for Creative Economy: Minister'. Jakarta Globe, 3 September.

Hill, H. (1996). The Indonesian Economy since 1996: Southeast Asia's Emerging Giant. Cambridge: Cambridge University Press.

ILO (2017). 'Informal Economy'. https://www.ilo.org/global/topics/employment-promotion/ informal-economy/lang--en/index.htm (accessed 5 May 2017).

IMF (International Monetary Fund) (2019). 'World Economic and Financial Surveys: World Economic Outlook Database'. Washington, DC: IMF. Available at: https://www.imf.org/external/pubs/ft/weo/2019/02/weodata/index.aspx (accessed 20 August 2019). 
Indonesia Investments (2018). '16th Economic Policy Package Indonesia: Investment, Tax Holiday and Export Earnings’. Indonesia Investments, 19 November.

Jacob, J. (2005). 'Late Industrialization and Structural Change: Indonesia, 1975-2000'. Oxford Development Studies, 33(3/4): 427-51.

Jacob, J., and C. Meister (2005). 'Productivity Gains, Technology Spillovers and Trade: Indonesian Manufacturing, 1980-96'. Bulletin of Indonesian Economic Studies, 41(1): 37-56.

Jones, G. (1966). 'The Growth and Changing Structure of the Indonesian Labour Force, 193081'. Bulletin of Indonesian Economic Studies, 2(4): 50-74.

Jütting, J., and J. de Laiglesia (2009). Is Informal Normal? Towards More and Better Jobs in Developing Countries. Paris: OECD Publishing.

Kim, K., A. Sumner, and A.A. Yusuf (2018). 'Is Structural Transformation-Led Economic Growth Immiserising or Inclusive? The Case of Indonesia'. ACDE Working Paper in trade and development 2018-11. Canberra: Australian National University.

Kim, K. (2019a). 'Indonesia's Restrained State Capitalism: Development and Policy Challenges'. Journal of Contemporary Asia, online 21 October.

Kim, K. (2019b). 'The State as a Patient Capitalist: Growth and Transformation of Indonesia's Development Financiers'. Pacific Review, online 1 March.

Kim, K., and A. Sumner (2019). 'The Five Varieties of Industrialisation: A New Typology of Diverse Empirical Experience in the Developing World'. ESRC GPID Research Network Working Paper 18. London: Global Poverty and Inequality Dynamics Research Network (GPID).

Kim, K., A. Sumner, and A. Yusuf (2017). 'A Job-Centred View of Inclusive Structural Transformation’. ESRC GPID Research Network Briefing Paper 7. London: GPID.

Kuznets, S. (1955). 'Economic Growth and Income Inequality'. The American Economic Review, 45(1): $1-28$.

Leigh, A., and P. Van der Eng (2009). 'Inequality in Indonesia: What Can We Learn from Top Incomes?' Journal of Public Economics, 93(1-2): 209-12.

Lewis, P. (2005). Growing Apart: Oil, Politics, and Economic Change in Indonesia and Nigeria. Ann Arbor: The University of Michigan Press.

Lindblad J. (2008). Bridges to New Business: The Economic Decolonization of Indonesia. Leiden: KITLV Press.

Lindert, P., and J. Williamson (2003). 'Does Globalization Make the World More Unequal?'. In M. Bordo, A. Taylor, and J. Williamson (eds), Globalization in Historical Perspective. Chicago: University of Chicago Press.

McCulloch, N. (2008). 'Rice Prices and Poverty in Indonesia'. Bulletin of Indonesian Economic Studies, 44(1): 45-63.

McMillan, M., and D. Rodrik (2011). 'Globalization, Structural Change and Productivity Growth'. In M. Bacchetta and M. Jansen (eds), Making Globalization Socially Sustainable. Geneva: International Labour Organization and World Trade Organization.

McMillan, M., D. Rodrik, and Í. Verduzco-Gallo (2014). 'Globalization, Structural Change, and Productivity Growth, with an Update on Africa’. World Development, 63(C): 11-32. 
Oberman, R., R. Dobbs, A. Budiman, F. Thompson, and M. Rossé (2012). The Archipelago Economy: Unleashing Indonesia's Potential. Jakarta: McKinsey Global Institute.

Pisani, E., M. Kok, and K. Nugroho (2017). 'Indonesia's Road to Universal Health Coverage: A Political Journey'. Health Policy and Planning, 32(2): 267-76.

PwC Indonesia (2018a). Mining in Indonesia: Investment and Taxation Guide, 10th Edition. Jakarta: PwC Indonesia.

PwC Indonesia (2018b). New Negative List of Investment: Opening New Opportunities for Foreign Investment. Tax Indonesia 2018/15. Jakarta: PwC Indonesia.

Radelet, S., J. Sachs, R. Cooper, and B. Bosworth (1998). 'The East Asian Financial Crisis: Diagnosis, Remedies, Prospects'. Brookings Papers on Economic Activity 1 (1998). Washington, DC: Brookings Institution Press.

Robison, R. (1986). Indonesia: The Rise of Capital. Sydney: Allen and Unwin.

Robison, R., and V. Hadiz (2004). Reorganising Power in Indonesia: The Politics of Oligarchy in an Age of Markets. New York: Routledge Curzon.

Robison, R., and V. Hadiz (2017). 'Indonesia: A Tale of Misplaced Expectation'. The Pacific Review, 30(6): 895-909.

Sen, K. (2014). 'Inclusive Growth: When May We Expect It? When May We Not?' Asian Development Review 31(1): 136-62.

Sen, K. (2019). 'Structural Transformation around the World: Patterns and Drivers'. Asian Development Review, 36(2): 1-31.

Soehoed, A. (1967). 'Manufacturing in Indonesia'. Bulletin of Indonesian Economic Studies, 3(8): 6584.

Suhaedi and P.A. Wibowo (2011). 'The Financial System: Balancing Financial Stability and Economic Growth'. In A. Ananta, M. Soekarni, and S. Arifin (eds), The Indonesian Economy: Entering a New Era. Singapore: Institute of Southeast Asian Studies.

Suryahadi, A., G. Hadiwidjaja, and S. Sumarto (2012). 'Economic Growth and Poverty Reduction in Indonesia before and after the Asian Financial Crisis'. Bulletin of Indonesian Economic Studies, 48(2): 209-27.

Szirmai, A. (1994). 'Real Output and Labour Productivity in Indonesian Manufacturing, 1975-90'. Bulletin of Indonesian Economic Studies, 30(2): 49-90.

The Economist (2019). 'Why Indonesia's President Has Made His Arch-Rival a Minister'. 24 October.

Thee, K. (1991). 'The Surge of Asian NIC Investment into Indonesia'. Bulletin of Indonesian Economic Studies, 27(3): 55-88.

Thee, K. (2006). Technology and Indonesia's Industrial Competitiveness. ADB Institute Research Paper Series 72. Tokyo: Asian Development Bank (ADB) Institute.

Thomas, T., and J. Panglaykim (1966). 'Indonesian Exports: Performance and Prospects 19501970, Part I'. Bulletin of Indonesian Economic Studies, 2(5): 71-102.

Timmer, M. (1999). 'Indonesia's Ascent on the Technology Ladder: Capital Stock and Total Factor Productivity in Indonesian Manufacturing, 1975-95'. Bulletin of Indonesian Economic Studies, 35(1): 75-97. 
Timmer, M.P., G.J. de Vries, and K. de Vries (2015). 'Patterns of structural change in developing countries'. In J. Weiss and M. Tribe (eds), Routledge Handbook of Industry and Development (pp. 65-83). Abingdon: Routledge.

UNU-WIDER. 'World Income Inequality Database' (WIID). Helsinki: UNU-WIDER.

Usui, N. (1997). 'Dutch Disease and Policy Adjustments to the Oil Boom: A Comparative Study of Indonesia and Mexico’. Resources Policy, 23(4): 151-62.

Van der Eng, P. (2009). 'Growth and Inequality: The Case of Indonesia, 1960-1997'. MPRA Paper 12725. Munich: Munich Personal RePEc Archive.

Van der Eng, P. (2010). 'The Sources of Long-Term Economic Growth in Indonesia, 1880-2008'. Explorations in Economic History, 47(2010): 294-309.

Van Leeuwen, B., and P. Földvári (2016). 'The Development of Inequality and Poverty in Indonesia, 1932-2008'. Bulletin of Indonesian Economic Studies, 52(3): 379-402.

World Bank (1981). Indonesia: Selected Issues of Industrial Development and Trade Strategy (Annex 1: The Structure of the Manufacturing Sector). Washington, DC: World Bank.

World Bank (1993). The East Asian Miracle: Economic Growth and Public Policy. Washington, DC: World Bank.

World Bank (2006). Indonesia: Making the New Indonesia Work for the Poor. Washington, DC: World Bank.

World Bank (2010). Indonesia Jobs Report: Towards Better Jobs and Security for All. Washington, DC: World Bank.

World Bank (2012). World Development Report 2013: Jobs. Washington, DC: World Bank.

World Bank (2013). Indonesia Economic Quarterly: Pressures Mounting (March 2013). Washington, DC: World Bank.

World Bank (2014a). East Asia Pacific at Work: Employment, Enterprise, and Well-Being. Washington, DC: World Bank.

World Bank (2014b). Indonesia Economic Quarterly: Delivering Change (December 2014). Washington, DC: World Bank.

World Bank (2014c). Indonesia Economic Quarterly: Hard Choices (July 2014). Washington, DC: World Bank.

World Bank (2015). Indonesia Economic Quarterly: In Times of Global Volatility (October 2015). Washington, DC: World Bank.

World Bank (2016). Indonesia Economic Quarterly: Resilience through Reforms (June 2015). Washington, DC: World Bank.

World Bank (2017a). Indonesia Economic Quarterly: Closing the Gap (October 2017). Washington, DC: World Bank.

World Bank (2017b). Indonesia Social Assistance Public Expenditure Review Update: Towards a Comprehensive, Integrated, and Effective Social Assistance System in Indonesia. Washington, DC: World Bank.

World Bank (2018). Indonesia Economic Quarterly: Towards Inclusive Growth (March 2018). Washington, DC: World Bank.

World Bank (2019a). 'PovcalNet'. http://iresearch.worldbank.org/PovcalNet/ povOnDemand.aspx (accessed on 20 September 2019). 
World Bank (2019b). 'World Development Indicators'. https://databank.worldbank.org/ reports.aspx? source $=$ world-development-indicators (accessed on 20 September 2019).

Yusuf, A., A. Sumner, and I. Rum (2014). 'Twenty Years of Expenditure Inequality in Indonesia, 1993-2013’. Bulletin of Indonesian Economic Studies, 50(2): 243-54. 